Article

\title{
Mineralogy of Paleocene Petrified Wood from Cherokee Ranch Fossil Forest, Central Colorado, USA
}

\author{
George E. Mustoe ${ }^{1, *}$ and Mike Viney ${ }^{2}$ \\ 1 Geology Department, Western Washington University, Bellingham, WA 98225, USA \\ 2 Poudre School District, Ft. Collins, CO 80526, USA; mviney@psdschools.org \\ * Correspondence: mustoeg@wwu.edu; Tel.: +1-360-650-3582 \\ Academic Editor: Jesus Martinez-Frias \\ Received: 3 February 2017; Accepted: 6 April 2017; Published: 10 April 2017
}

\begin{abstract}
An extensive fossil forest discovered in 2010 on private property in central Colorado, USA, has not previously been described in scientific literature. Horizontal partial logs originated as fluvially transported driftwood. A preliminary study of petrified wood specimens reveals evidence of a complex mineralization sequence that involved multiple episodes of mineral deposition, combined with diagenetic transformation of silica minerals. Specimens from two logs have opalized cell walls. However, minerals filling the cell interiors of these specimens vary. Vessel lumina are filled with chalcedony or crystalline quartz; tracheid lumina may contain opal or chalcedony. Specimens from 5 other logs contain quartz/chalcedony, but relict textures suggest cell walls were originally mineralized with opal that was later converted to microcrystalline silica. Pyrite, calcite, and iron oxides were observed as minor constituents in some specimens, providing additional evidence that fossilization occurred in multiple stages, with temporal and spatial variations in physical and chemical conditions causing episodic precipitation of various minerals within the buried wood. Trace element analyses suggest that $\mathrm{Fe}$ is the main source of fossil wood color.
\end{abstract}

Keywords: chalcedony; Cherokee Ranch; Colorado; Denver Basin; opal-A; opal-CT; petrified wood

\section{Introduction}

Petrified wood described in this report is from Paleocene strata exposed at Cherokee Ranch, Douglas County, Colorado, USA (Figure 1). The Cherokee Ranch Petrified Forest consists of small, silicified specimens of various sizes along with 30 plus partial logs scattered over an area of 81 hectares. A striking feature of this locality is the size and abundance of fossil logs, comprising one of the most extensive fossil forests in the Rocky Mountain region. This preliminary report considers the mineralogy and geochemistry of the fossil wood, but the main goal is to provide the first scientific description of the locality. Details of the history, geology, and paleobotany will be presented in a future report.

Cherokee Ranch is nestled along the Front Range approximately $51 \mathrm{~km}$ south of Denver. The private ranch has had restricted access since the early 1950's. Since 1996, this 1376 hectare (3400 acre) property has been protected from development by a Conservation Easement, under the direction of the Cherokee Ranch and Castle Foundation. The stewardship provided by this land trust led to the rediscovery of the fossil forest, one of the largest in the Rocky Mountain region. Although petrified logs were observed by settlers of European ancestry in the late 1800's (and probably much earlier by Native Americans), the first comprehensive studies began in 2010, when John McKinney discovered numerous partially buried fossil logs $1.5 \mathrm{~km}$ southeast of the castle [1]. A volunteer-led research team subsequently mapped the distribution of fossil logs.

The Cherokee Castle (formerly known as Charlford Castle), a historic centerpiece to this property, was constructed between 1924 and 1926 (Figure 2). The Cherokee Castle's design integrates 
architectural elements inspired by mid-15th century English and Scottish castles. It is estimated that 4000 pieces of locally collected fossil wood are incorporated into the castle's walls and arches.
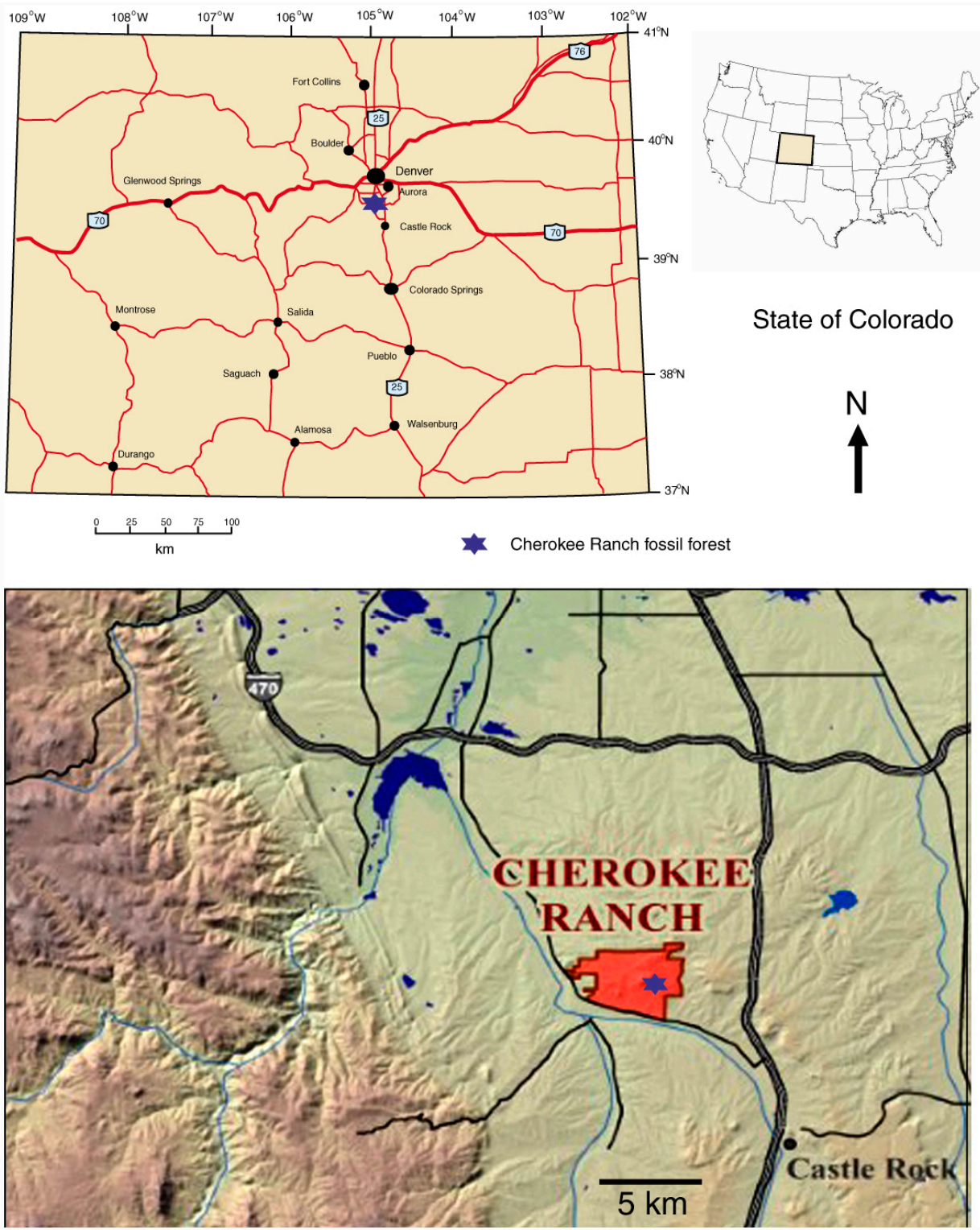

Figure 1. Location map.

\section{Geologic Setting}

The petrified forest is preserved within the Dawson Arkose, a sequence of fluvial and alluvial fan deposits within the Denver Basin. This large asymmetric syncline lies at the eastern side of the Front Range, a subrange within the Colorado Rocky Mountains (Figure 3). The basin initially formed about 300 million years ago from an orogeny that created the Ancestral Rocky Mountains. Basin deposits include a thick sequence of sediments deposited in the Cretaceous Inland Seaway. The Denver Basin was deepened during the Paleogene Laramide Orogeny, which created the modern Colorado Rockies; sediments are mostly composed of material eroded from the new mountain range. Age constraints are well established for Denver Basin stratigraphic members, based on magnetostratigraphy, radiometric ages, palynostratigrapahy, and vertebrate fossils [2-5]. 

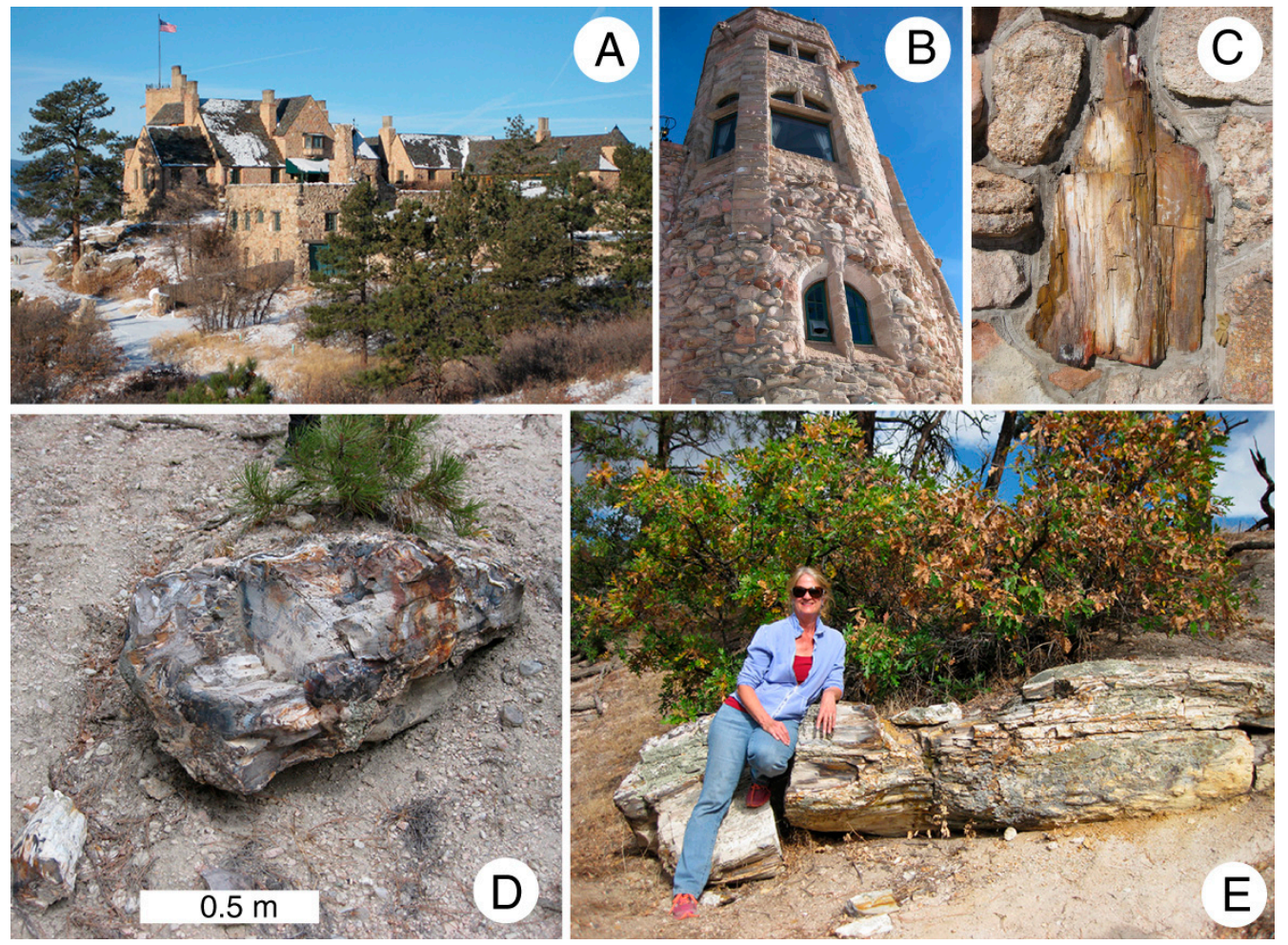

Figure 2. Cherokee Ranch, Douglas County, Colorado USA. (A,B) Cherokee Castle; (C) petrified wood in castle wall; (D,E) Horizontal silicified logs at Cherokee Ranch fossil forest. Photos by Mike Viney.

Alluvial fan and fluvial deposits that comprise the Dawson Arkose were formed during the Late Cretaceous and Early Tertiary. The lower Dawson Arkose beds formed during the early Paleocene, and interfinger with the Denver Formation, which spans the Cretaceous-Paleogene boundary (Figure 4). Younger Dawson Arkose beds are Eocene. Two unconformity-bound sequence stratigraphic units have been described to facilitate basin-wide stratigraphic comparisons [3]. The 275-550m thick D1 sequence includes the Arapaho, Denver, and lower Dawson Arkose Formations. The base of the D1 is defined by the abrupt facies change at the top of the Laramie Formation; the top boundary is a regional paleosol. The D2 sequence consists of Dawson Arkose sediments that overly the paleosol, the upper boundary being the unconformable contact with the late Eocene Castle Rock conglomerate. Thickness of the D2 sequence varies from 30 to $300 \mathrm{~m}$.

The D1 sequence has considerable variation in composition because of its origin as a catch-basin for sediment washing down from the slopes of the rapidly-rising mountain range. Conglomerate beds occur at the base of the sequence and also at higher levels in the western part of the basin, the zone of deposition closest to the mountain slopes. The eastern basin contains thick lignite beds [6]. The D1 sequence is dominated by fluvial sandstone beds that contain mainly arkosic sediment. Alluivial fan deposits are also present, along with finer interbeds that represent palludal and lacustrine deposition [7]. Leaf fossils have been reported from many Denver Basin localities, ranging in age from Late Cretaceous to early Eocene $[7,8]$.

Silicified wood occurs in upper D1 Paleocene strata and in the overlying Eocene D2 beds [9]. The Cherokee Ranch fossil forest lies within the upper part of the D1 sequence, just below the upper boundary paleosol. The age estimate for the fossil forest comes from its stratigraphic proximity to this $\sim 55$ Ma paleosol (Figures 3 and 4). All silicified wood specimens examined thus far are angiosperms that exhibit a diffuse porous wood structure with indistinct growth rings. Wood colors include white, yellowish orange, and black, but tan and brown are the most common hues. The very small magnitude 
of carbon X-ray peaks in SEM/EDS spectra and the absence of visible organic matter in optical microscope and SEM images are evidence that very little organic matter is preserved.

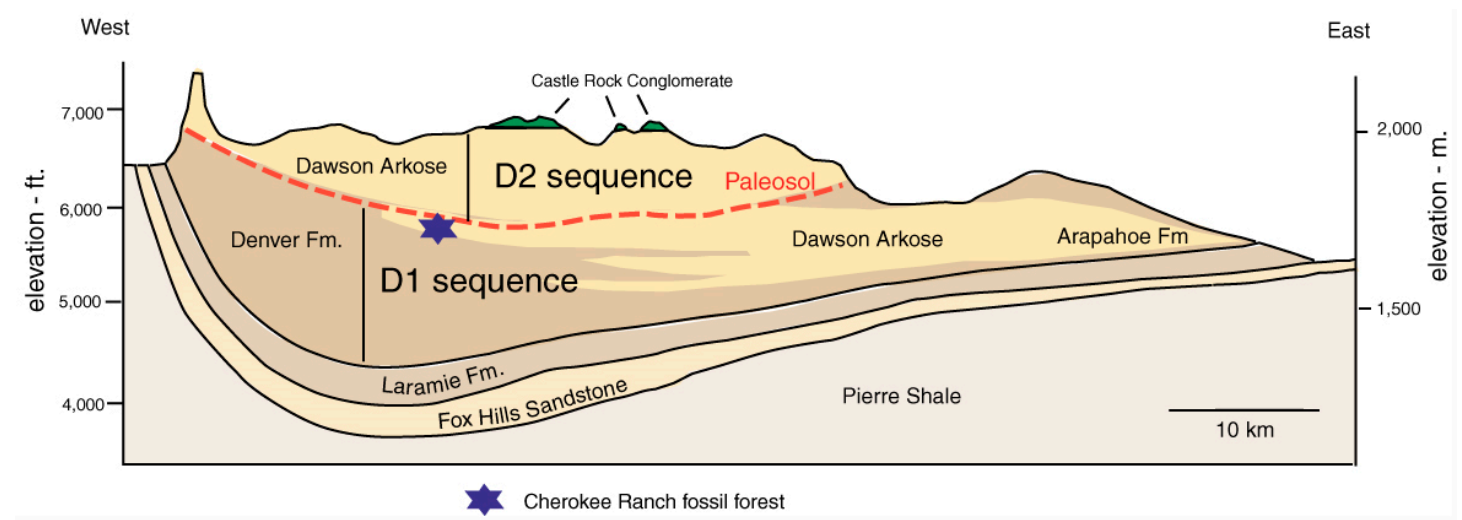

Figure 3. Generalized cross section view of the Denver Basin syncline. Relative ages of rock units are shown in Figure 4. Adapted from Roberts et al. [10] and Johnson et al. [7].

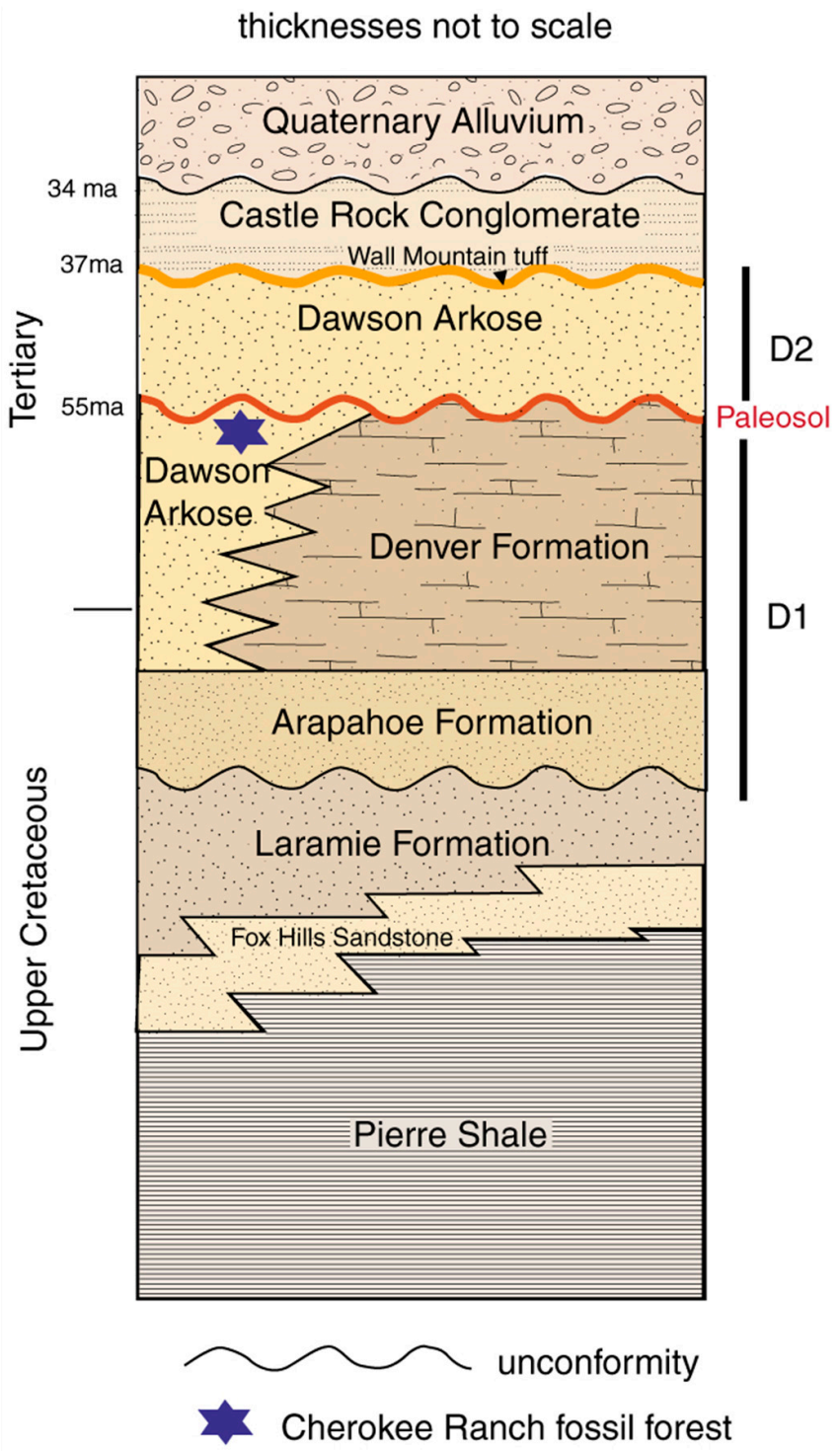

Figure 4. Generalized stratigraphic section of Denver Basin strata. Adapted from Roberts [10]. 
Fossil log sections are partial rounds found prostrate with no limbs or bark. They are enclosed in an arkosic sandstone matrix that includes large well-rounded quartz grains and smaller angular quartz and feldspar clasts, with siliceous intergranular cement produced by devitrification of tephra (Figure 5). These characteristics indicate that the wood is an allochthonous deposit, where tree trunks and wood fragments were deposited as driftwood on sandbars along an ancient river. The tuffaceous matrix and abundant feldspar clasts provided sources of silica for wood petrifaction.

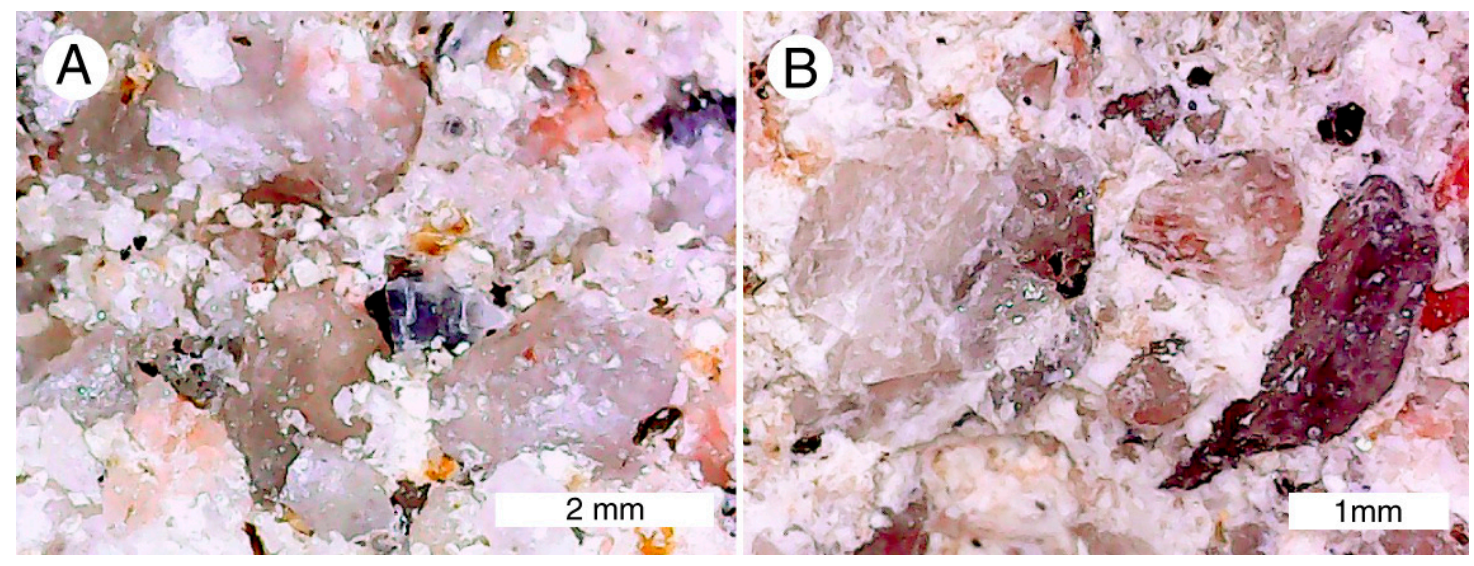

Figure 5. Arkosic sandstone that encloses Cherokee Ranch fossil logs comprises large well-rounded quartz grains and smaller angular grains of quartz and feldspar in a siliceous matrix produced by devitrification of tephra. (A) sample CR-457; (B) Sample CR-456.

\section{Methods}

Specimens used in this study were provided courtesy of Cherokee Ranch and Castle Foundation. Scanning electron microscope analyses were made using a TescanVega SEM, equipped with an EDAX non-dispersive X-ray spectrometer with Genesis software. X-ray diffraction patterns came from a Rigaku Geigerflex diffractometer using Ni-filtered $\mathrm{Cu}-\alpha$ radiation. Density values of wood samples were determined using a Mettler analytical balance equipped with a hydrostatic weighing device. Trace element determinations were made on polished slabs using an Agilent 7500ce ICP-MS spectrometer with a New Wave UP123 laser ablation system to ablate six, $3 \mathrm{~mm} \times 0.55 \mathrm{~mm}$ tracks on each sample [11].

\section{Results}

Seven Cherokee Ranch fossil wood specimens were examined, six from the main fossil forest and one, sample West Shard, from an outlier site. The mineralogy of these samples was studied using a variety of methods in an attempt to determine the composition, and to infer the mineralization sequence that produced the fossil wood.

\subsection{Petrography: Transmitted Light Microscopy}

Transmitted polarized light microscopy is a useful tool for recognizing silica polymorphs in petrified wood. Opal-A has an amorphous structure that inhibits the transmission of polarized light, causing this form of opal to be isotropic (i.e., opaque black). Weak crystallinity causes opal-CT to show dim interference colors, in contrast to the brighter colors characteristic of chalcedony and quartz. Optical microscopy also provides anatomical information for samples where cell features can be distinguished based on color variations.

Polarized light microscopy has several limitations. Petrographic slides are typically prepared to have a thickness of $30 \mu \mathrm{m}$, and interference colors are evaluated for this specimen thickness. However, if a mineral is present as an aggregate of small particles, the observed interference colors are 
determined by the diameters of the individual particles, which may be much less than $30 \mu \mathrm{m}$. This phenomenon may hinder discerning between opal-A and opal-CT.

Chalcedony and microcrystalline quartz show similar interference colors. Chalcedony may be recognizable because of textural features that affect optical properties. Chalcedony may have a fibrous structure, or occur as a myriad of polygonal twinned crystals. Both features may be revealed by polarized views. However, when particle sizes are small (e.g., silica within individual wood cells) chalcedony and microcrystalline quartz may be indistinguishable. In the following descriptions, we use "quartz" as a general descriptive term, except in instances where chalcedony textures are clearly evident.

Five specimens from the main fossil forest assemblage all contain quartz as the only recognizable forms of silica (Figure 6). This material is present as filling material in the lumina of individual tracheids, and in larger vessels.
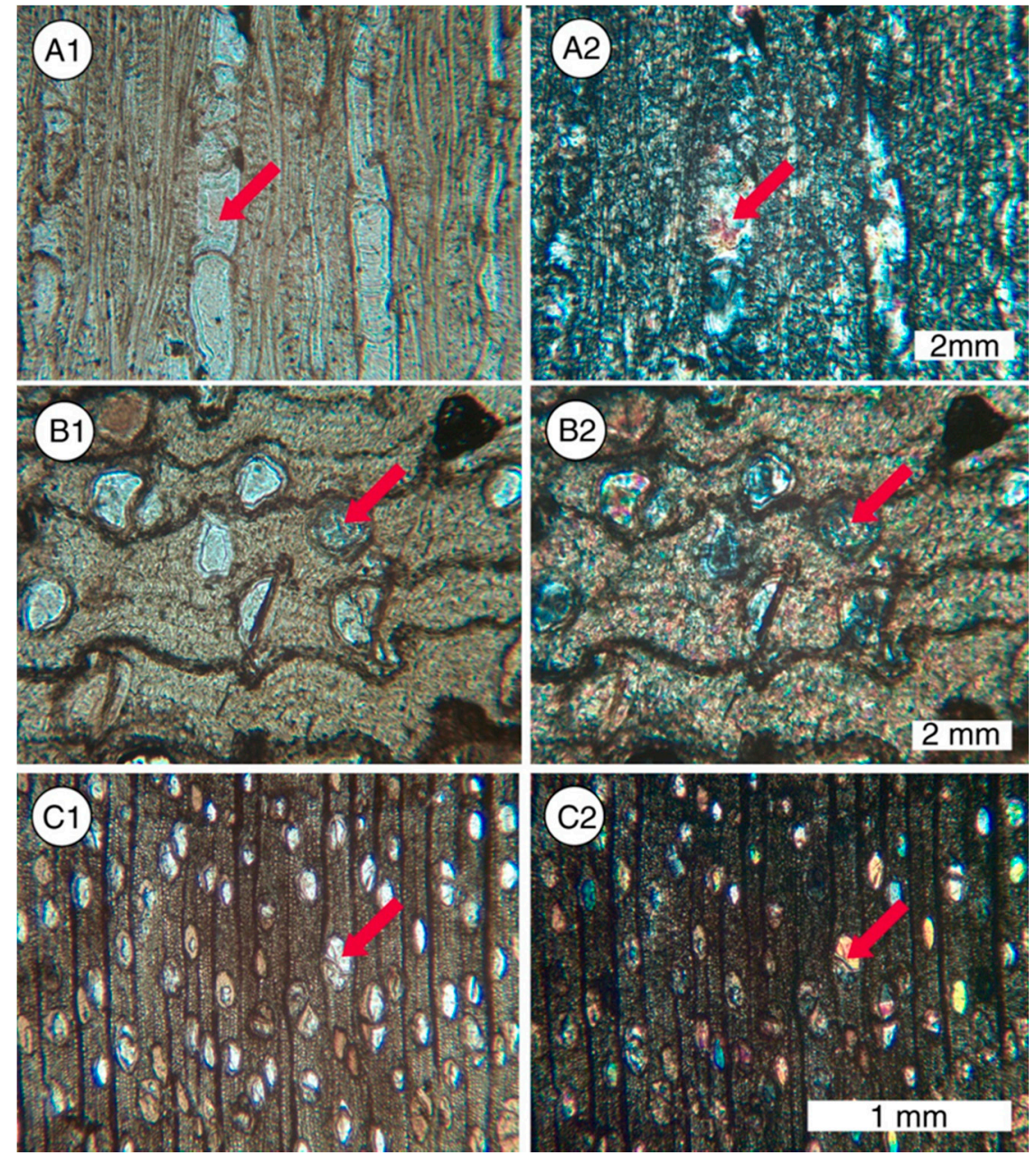

Figure 6. Quartz-mineralized wood. For each photo pair, image 1 is ordinary transmitted light view, image 2 is transmitted polarized light view. (A) Sample CR-14, tangential orientation, showing longitudinal-section of quartz-filled vessel (arrows); (B) Sample CR-12, transverse orientation, showing distorted cell walls and quartz-filled vessels (arrows); (C) Sample CR-1, transverse view, showing quartz-filled vessels (arrows).

The two samples, CR-40 and West Shard, exhibit cell walls that are mineralized with opal (Figures 7 and 8). Mineralization of cell interiors (lumina) is variable, even within a single small specimen. In the CR-40 specimen, some areas exhibit tracheids with opal-filled interiors, while vessel interiors are quartz filled. In other areas, the interiors of both tracheids and vessels are quartz filled. Polarized light views 
of vessels show that this quartz filling is in the form of chalcedony (Figure 7B). Sample West Shard (Figure 7C) contains many irregularly shaped zones of chalcedony mineralized wood. In these zones, cell walls are mineralized with chalcedony instead of opal. The irregularly shaped areas may represent decayed zones that remained unmineralized during early opal precipitation, leaving permeable zones where chalcedony was precipitated during a later mineralization episode.

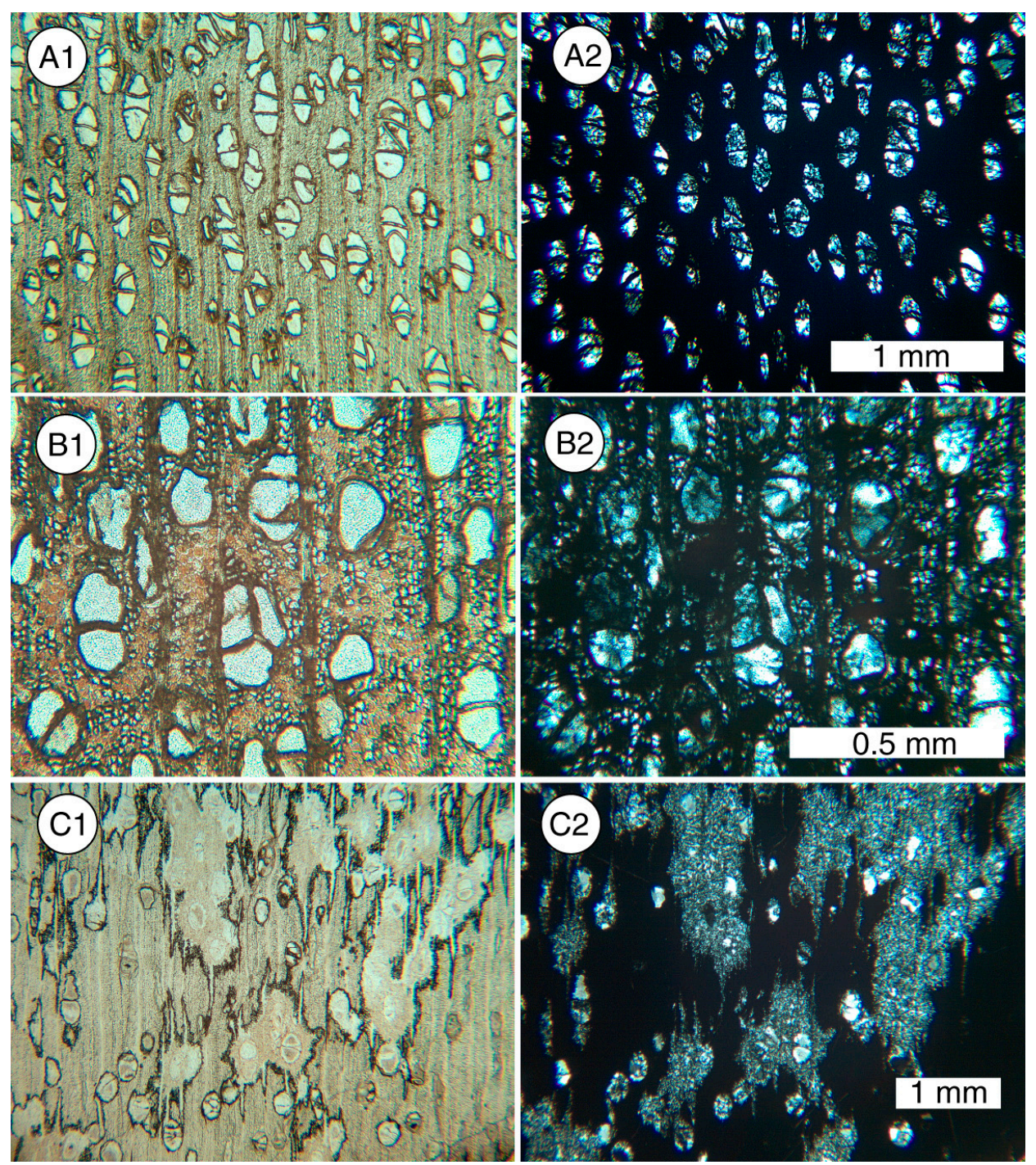

Figure 7. Partially opalized wood. For each photo pair, image 1 is ordinary transmitted light view, image 2 is transmitted polarized light view. (A) Sample CR-40, transverse orientation, showing an area where walls are mineralized with opal, with opal filling the tracheids, and chalcedony filling the vessels; (B) Sample CR-40, transverse orientation, showing an area where tracheids and vessels are quartz-filled. Light brown areas in vessels may be amorphous iron oxide. Although vessels are quartz filled, internal partitions (tyloses) are mineralized with opal. Polarized light image shows the quartz vessel filling is in the form of wedge-shaped twinned crystals of chalcedony; (C) Sample West Shard, transverse orientation. This specimen shows areas of opalized tissue, where some vessels are filled with quartz or chalcedony, and other vessels contain opal. The slide shows prominent irregular zones that appear to be decayed areas that are permineralized with chalcedony. 


\subsection{Petrography: Reflected Light Microscopy}

Reflected light examination of polished wood slabs provides different visual images of the specimens, compared to transmitted light images of thin sections, but the same basic anatomical and mineralogic features are evident (Figure 8).

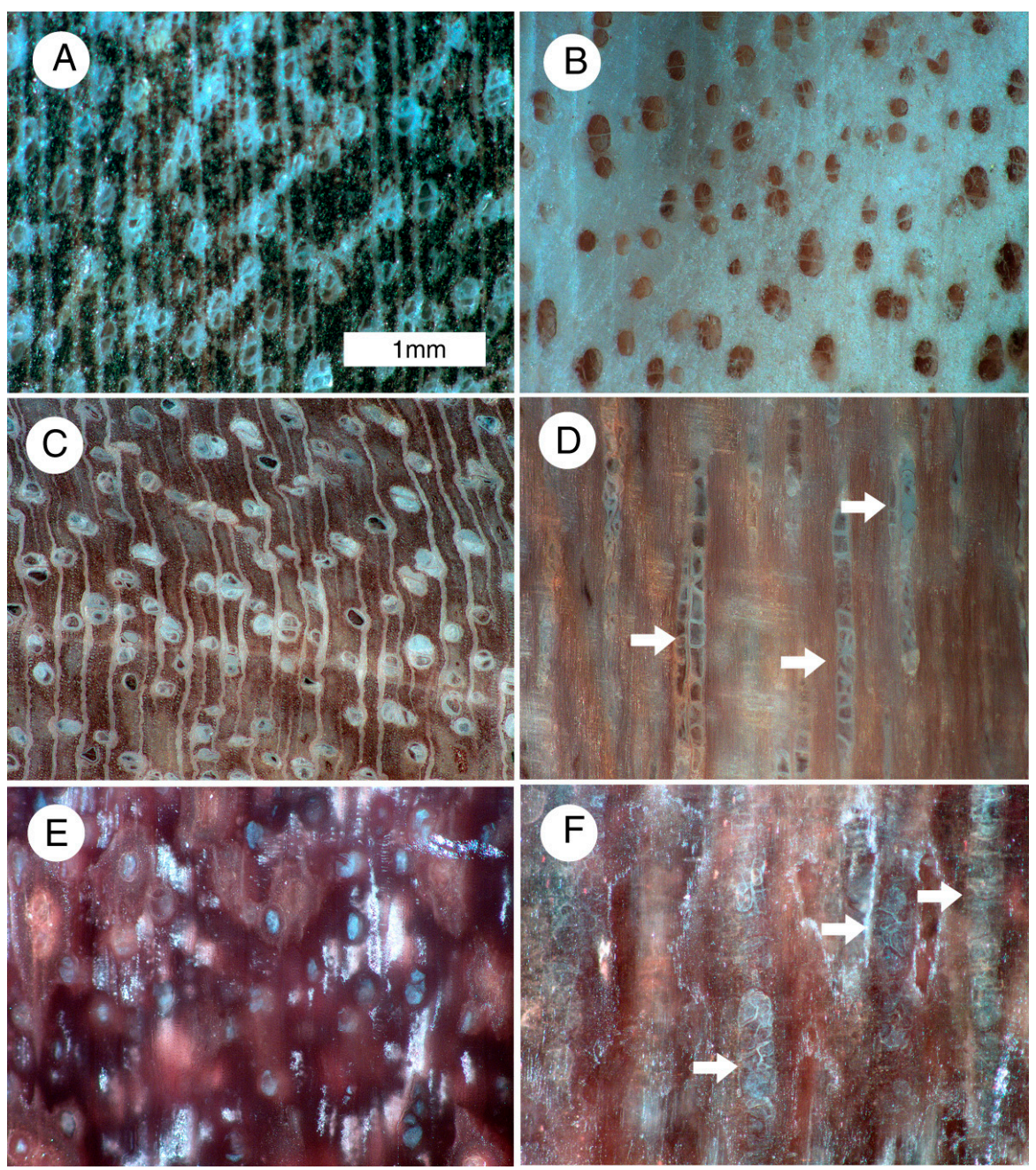

Figure 8. Reflected light photomicrographs of polished wood specimens. (A,B) Sample CR-40, transverse orientation, showing chalcedony filled vessels. $A=$ dark brown wood, B = white wood; (C) Sample CR-12, transverse orientation. Most vessels are filled with chalcedony, but some vessels remain open, with only a thin lining of chalcedony; (D) Sample CR-12, orientation, showing cross-section views of chalcedony-filled ray cells. These cells contain a white lining layer, with gray chalcedony filling the central area; (E) Sample West Shard, transverse orientation. Reddish areas have opalized cell walls, whitish areas are presumed to be decayed areas that became mineralized with chalcedony. Vessels contain chalcedony; (F) Sample West Shard, tangential orientation. Vessels (arrows) contain gray chalcedony.

\subsection{X-ray Diffraction}

X-ray diffraction patterns are useful for recognizing silica polymorphs. Because of its amorphous nature, opal-A does not produce diffractions peaks. Opal-CT yields weak peaks characteristic of cristobalite/tridymite. Quartz and chalcedony produce strong peaks, but the two minerals usually are not distinguishable based on XRD patterns. There are other analytical limitations. Because opal-A can only be recognized by the absence of peaks, the diffraction pattern of a sample containing opal-A 
and opal-CT would be identified as containing opal-CT. The relatively weak peaks characteristic of opal-CT may make this mineral difficult to identify when well-crystallized minerals are present. When opal-CT and quartz are both present, the great discrepancy between intensity ratios hinders estimation of the relative amounts of the two minerals.

XRD patterns (Figure 9) reveal the presence of opal-CT in samples CR-40 and West Shard, the two specimens where opaline cell walls could be observed in thin sections. Samples CR-1, 5, 12, 14, and 16 show quartz as the only crystalline component, results that are consistent with optical microscopy.

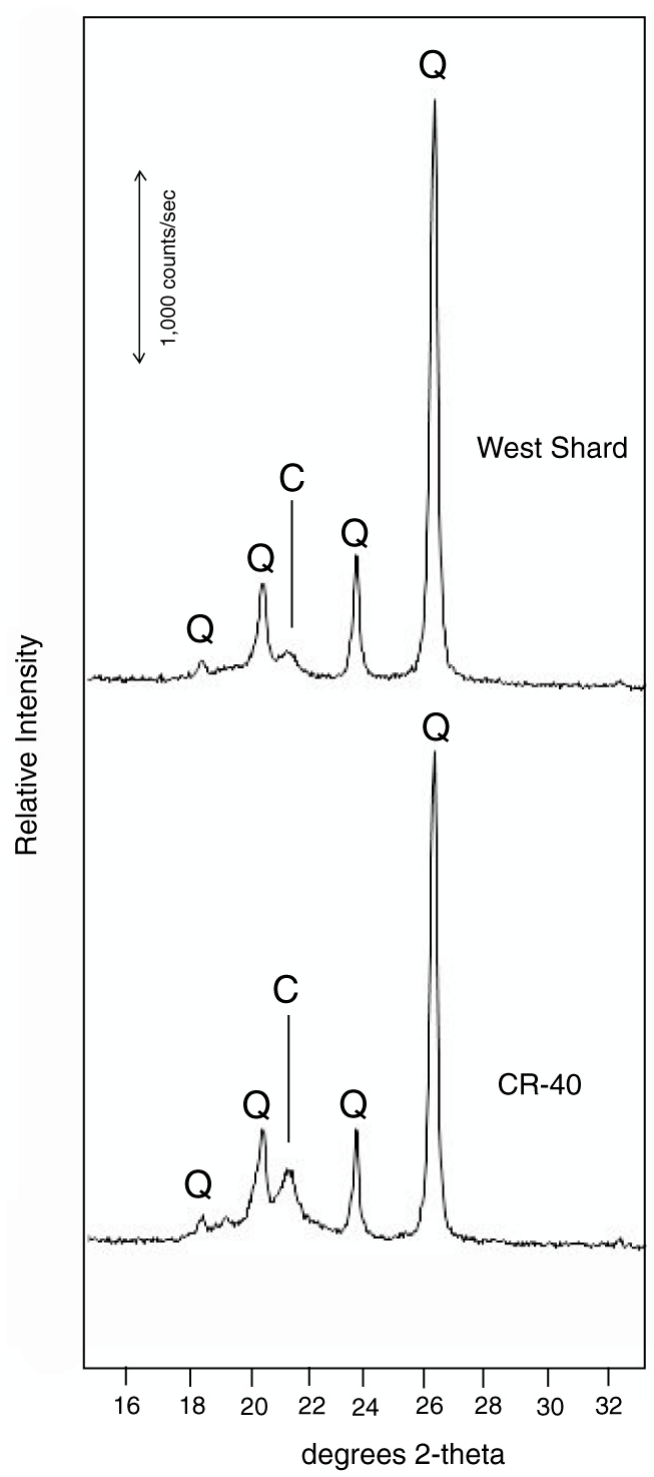

Figure 9. X-ray diffraction patterns for samples $C R-40$ and West Shard. $Q=$ quartz, $C=$ cristobalite (opal-CT).

\subsection{Density}

Relative abundance of quartz and opal can be semi-quantitatively estimated based on specimen density. Observed densities of woods mineralized with quartz or chalcedony are $2.3-2.1 \mathrm{~g} / \mathrm{cm}^{3}$, and $1.9-2.1 \mathrm{~g} / \mathrm{cm}^{3}$ for opalized wood [12]. For samples that contain a mixture of silica minerals, the measured density will be intermediate between the values for the end members, allowing relative proportions of opal and quartz/chalcedony to be estimated. The main constraint governing the accuracy of this method is the requirement that the fossil wood is well mineralized, i.e., contains only 
small amounts of relict organic matter. The paucity of organic matter in Cherokee Ranch specimens is verified by the very low magnitude of carbon peaks in SEM/EDS spectra and the absence of visible microscopic evidence of relict cellular tissue. Table 1 lists density values calculated for various quartz/opal ratios and estimated results for Cherokee Ranch samples. These data are consistent with optical microscopy and XRD patterns. For both samples, optical micrographs show that quartz-filled vessels occupy a relatively large part of the fossil wood volume. Sample CR-40 shows areas where cell lumina are opalized, consistent with lower density. Opal in sample West Shard is primarily located in the thin cell walls, the mineral barely discernable in XRD patterns. Opal makes a negligible contribution to specimen density for samples West Shard and CR-40.

Table 1. Density of various quartz/opal mixtures, including wood specimens from Cherokee Ranch fossil forest.

\begin{tabular}{|c|c|c|c|}
\hline$\%$ Quartz & $\%$ Opal & \multirow{2}{*}{\multicolumn{2}{|c|}{ Calculated Density $\left(\mathrm{g} / \mathrm{cm}^{3}\right)$}} \\
\hline$d=2.50 \mathrm{~g} / \mathrm{cm}^{2}$ & $d=2.0 \mathrm{~g} / \mathrm{cm}^{2}$ & & \\
\hline 0 & 100 & \multicolumn{2}{|c|}{2.00} \\
\hline 10 & 90 & \multicolumn{2}{|c|}{2.05} \\
\hline 20 & 80 & \multicolumn{2}{|c|}{2.10} \\
\hline 30 & 70 & \multicolumn{2}{|c|}{2.15} \\
\hline 40 & 60 & \multicolumn{2}{|c|}{2.20} \\
\hline 50 & 50 & \multicolumn{2}{|c|}{2.25} \\
\hline 60 & 40 & \multicolumn{2}{|c|}{2.30} \\
\hline 70 & 30 & \multicolumn{2}{|c|}{2.35} \\
\hline 80 & 20 & \multicolumn{2}{|c|}{2.40} \\
\hline 90 & 10 & \multicolumn{2}{|c|}{2.45} \\
\hline 100 & 0 & \multicolumn{2}{|c|}{2.50} \\
\hline \multicolumn{4}{|c|}{ Results for Cherokee Ranch samples } \\
\hline$\%$ quartz & \% opal & Density & Sample \\
\hline 75 & 25 & 2.37 & CR-40 \\
\hline 100 & 0 & 2.49 & W. Shard \\
\hline 100 & 0 & 2.50 & CR-1 \\
\hline 100 & 0 & 2.48 & CR-5 \\
\hline 100 & 0 & 2.54 & CR-12 \\
\hline 100 & 0 & 2.53 & CR-14 \\
\hline 100 & 0 & 2.51 & CR-16 \\
\hline
\end{tabular}

\subsection{Scanning Electron Microscopy}

Scanning electron microscopy provides a powerful tool for studying the mineralogy and anatomy of fossil wood. Minerals may be recognizable purely from their physical form. In addition, an X-ray fluorescence spectrometer can reveal their chemical composition. Backscattered electron (BSE) SEM images primarily show surface topography and exhibit excellent anatomical detail when specimens are not completely mineralized. In specimens where intracellular spaces remain open, SEM images may show individual cells in great detail. If cell lumina remain open, anatomy of cell walls can more readily be observed. Secondary electron images of specimen surfaces can provide excellent anatomical detail. However, these images are only successful when the wood is not completely mineralized. When all spaces are mineralized, SEM images may appear rather featureless. However, even these samples may contain local areas where incomplete mineralization reveals structural details.

Crystal shapes are most likely to be present when minerals precipitate in unconfined spaces, where well-ordered lattices grow unimpeded to form euhedral crystals rather than dense microcrystalline masses. This phenomenon explains the occurrence of quartz crystals within vessels, which remained open during initial stages of petrifaction.

The observation that Cherokee Ranch wood specimens commonly show wood grain textures on radial and tangential surfaces that are visible to the naked eye is evidence that tissues are not fully 
mineralized, suggesting they are good candidates for SEM analysis. At relatively low magnification, most of the wood specimens clearly show the fibrous structure of the original wood (Figure 10). The only exception is sample West Shard, which has a glossy, vitreous appearance.

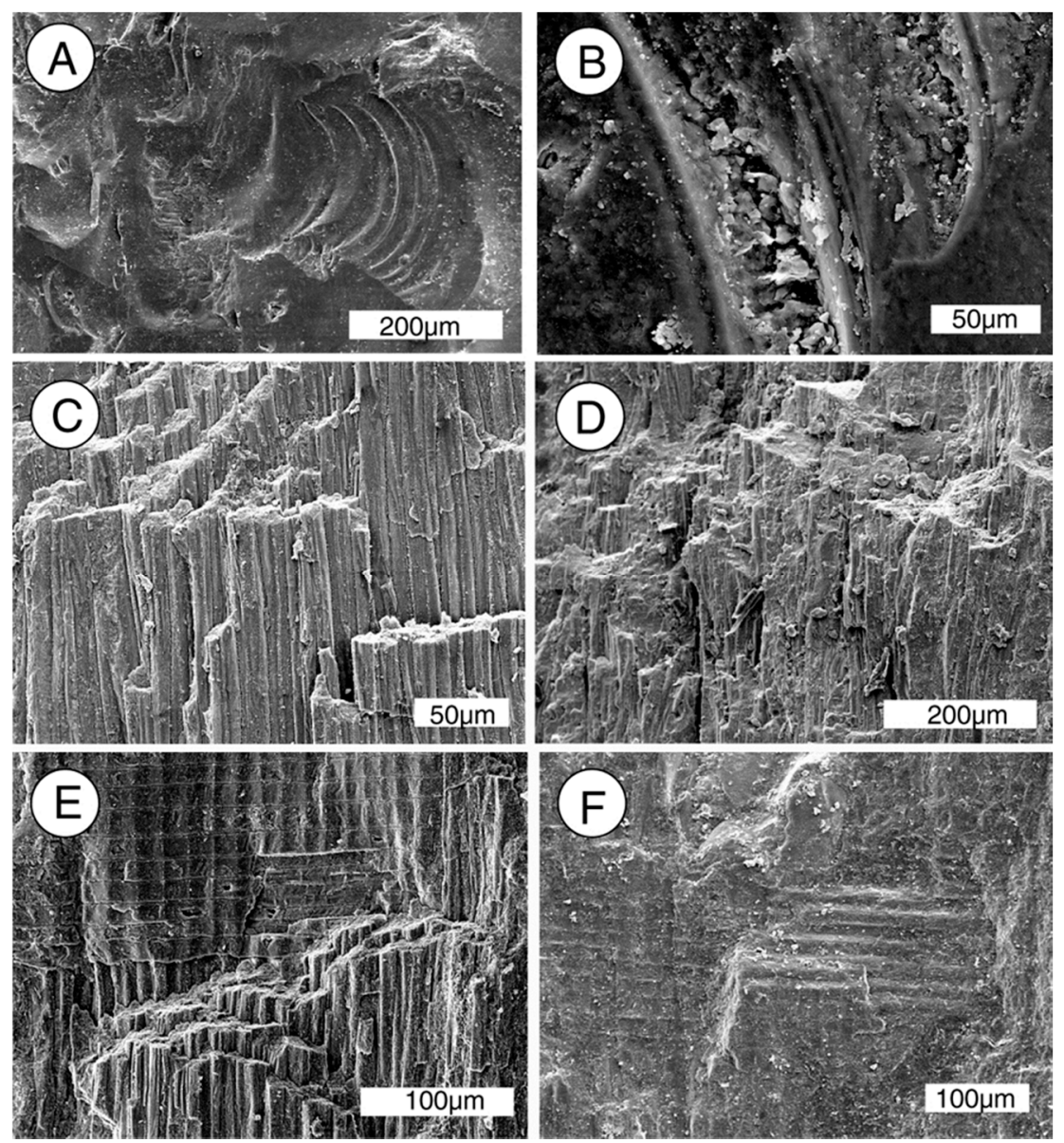

Figure 10. SEM images of Cherokee Ranch specimens. (A) West Shard is so completely mineralized that fractured surfaces have a vitreous appearance, where conchoidal fractures are the most obvious topographic feature; (B) At high magnification, the concentric fractures contain many small irregularities; (C) Sample CR-1, radial orientation, showing tracheids separated by partially unmineralized intracellular spaces; (D) Sample CR-5, tangential orientation. Intracellular spaces have more mineralization than the previous photo, resulting in fracture surfaces that show less topographic cellular detail; (E) Sample CR-12, radial orientation. Partial mineralization of intracellular spaces causes the wood to fracture resulting in stair-stepped topography. Note the horizontal ray cells visible in the upper left image area; (F) Sample CR-14, radial orientation. More complete mineralization of intracellular spaces causes fracture surfaces to be relatively featureless. Horizontal ray cells are faintly visible.

The five samples from the main fossil forest area all show similar features (Figure 11). At high magnification, the lumina of vessels and tracheids can be seen to contain crystalline quartz. Cell walls are also mineralized with quartz that has a very fine granular surface texture. Locally, cell wall surfaces may be overgrown with tiny quartz crystals (Figure 11D). Quartz within tracheid lumina consists of an aggregate of small crystallites (Figure 11D), in contrast to subhedral crystals that fill the lumina of vessels (Figure 11C).

Two samples (CR-40 and West Shard) that contain opal as a constituent show some additional features. These include tabular microcrystals of opal-CT, smooth-textured opal (Figures 12 and 13), and small amounts of non-silica minerals (Figures 14 and 15). 

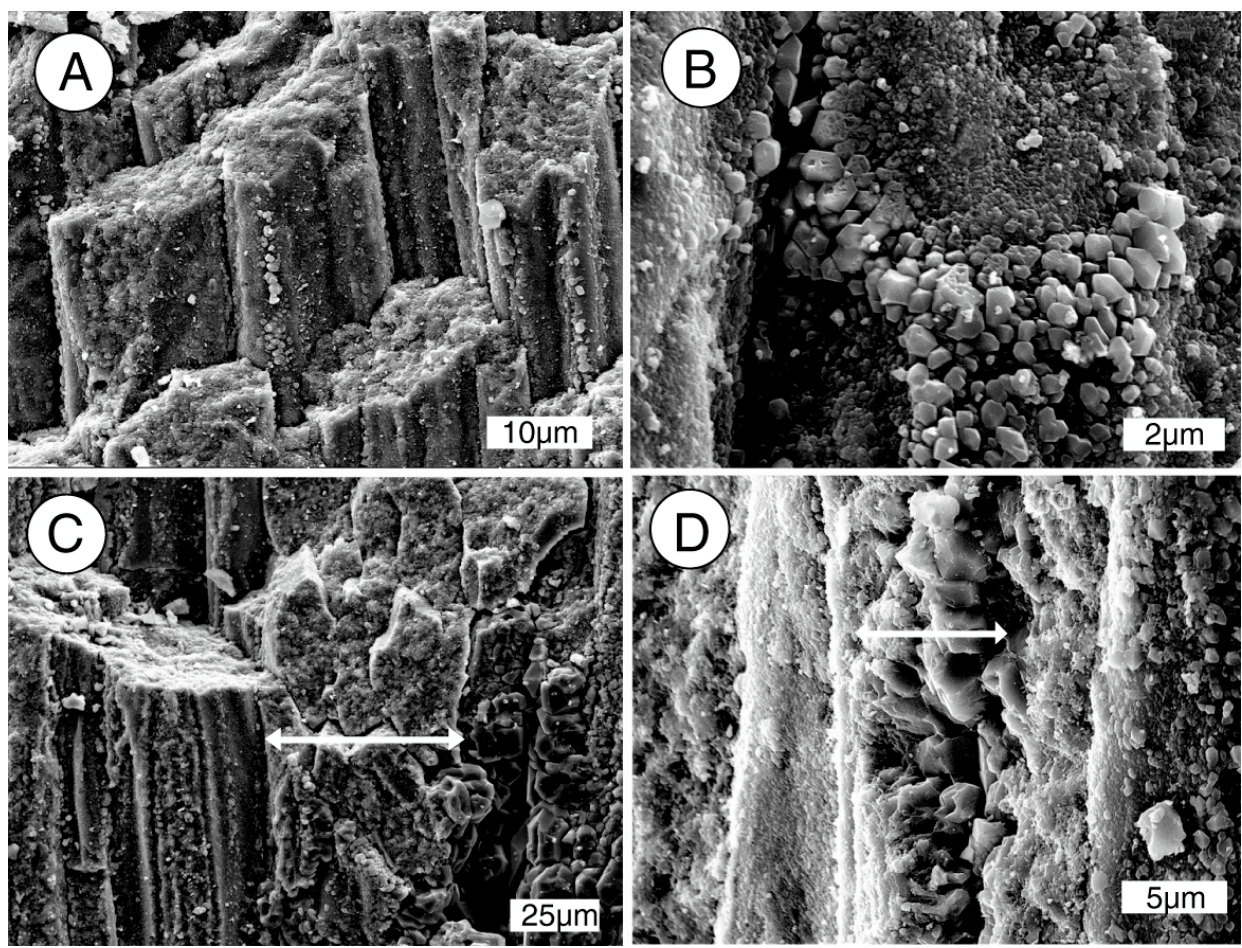

Figure 11. (A,B) Sample CR-1, oblique transverse orientation. Cell walls are mineralized with quartz, lumina contain quartz having finer texture; (C) Sample CR-5, radial orientation, showing $50 \mu \mathrm{m}$ wide vessel filled with crystalline quartz (arrow); (D) Sample CR-12, radial orientation, showing crystalline quartz filling a cell lumen (arrow). Note the fine granular texture of the adjacent quartz-mineralized cell walls, perhaps a relict of an opal precursor.
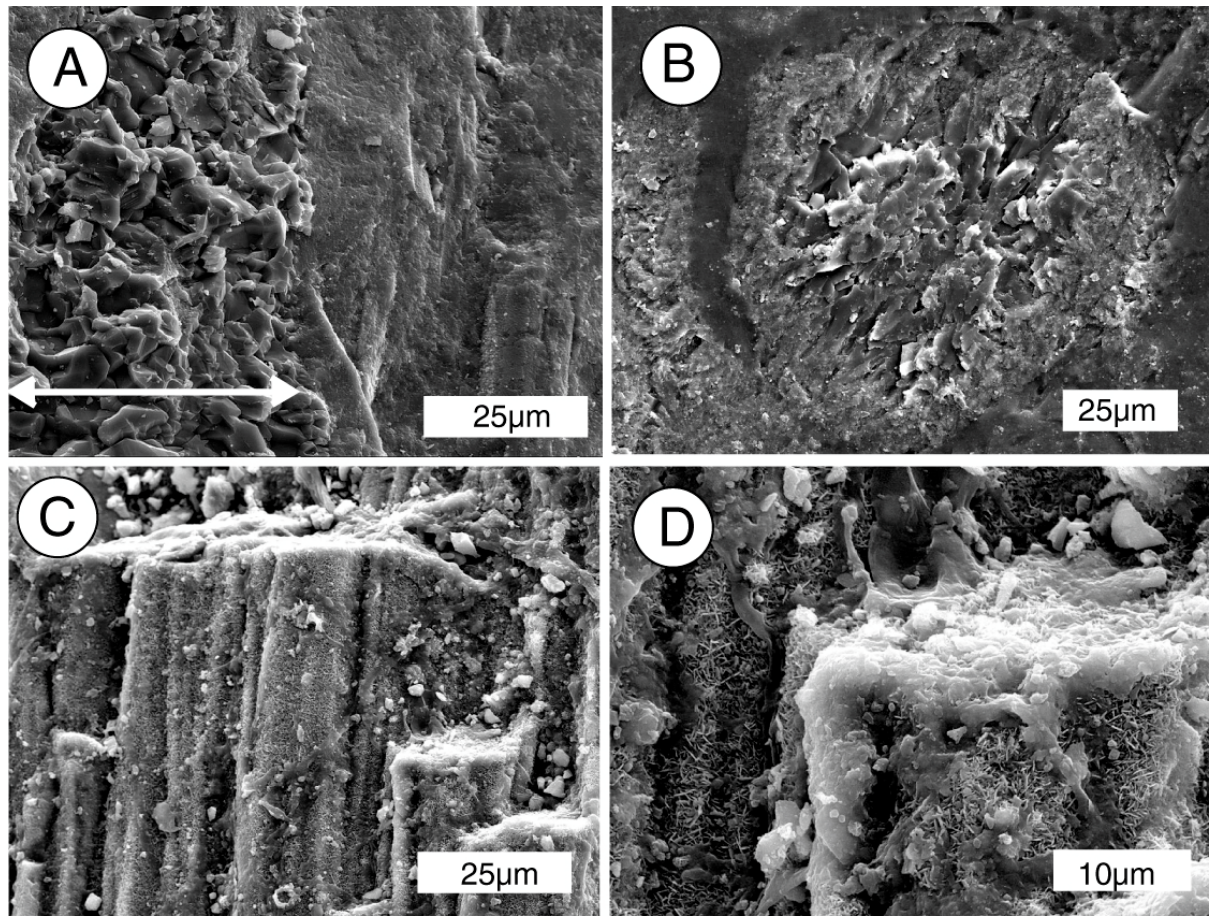

Figure 12. SEM images of sample CR-40. (A) Radial view, showing crystalline quartz filling a vessel (arrow); (B) Transverse orientation, showing a single vessel containing quartz, bordered by a thin opalized cell wall; (C,D) Radial orientation. Exterior surfaces of tracheids show the "corn flake" crystal texture typical of opal-CT. 

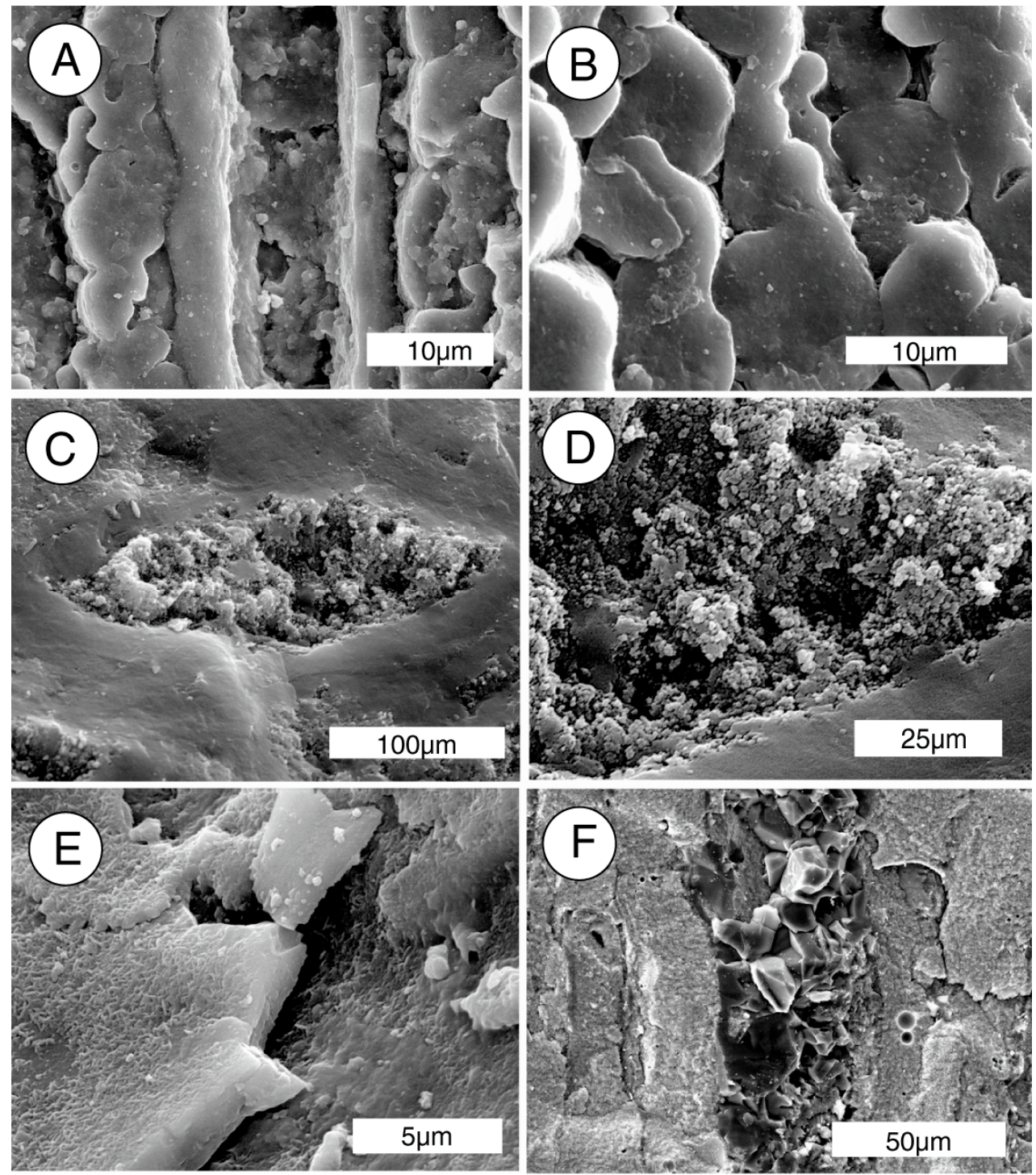

Figure 13. SEM images of sample West Shard. (A) Radial orientation, showing a tracheid with opalized cell walls, and an empty lumen; (B) Radial orientation, showing smooth-textured opal on several adjacent tracheids; (C,D) Oblique transverse view of a vessel. Cell walls are mineralized with smooth-textured opal, vessel contains a multitude of microspheres, perhaps a relict texture of opal-A; (E) High-magnification view of a cell wall, showing opal-CT crystals on the upper surface; (F) Radial orientation, vessel filed with subhedral quarts crystals, bordered by opalized cell walls.
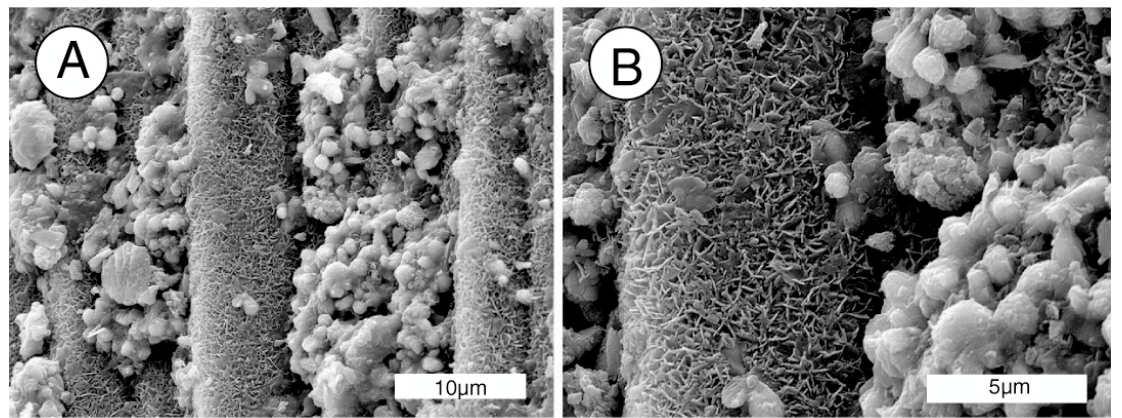

Figure 14. Cont. 

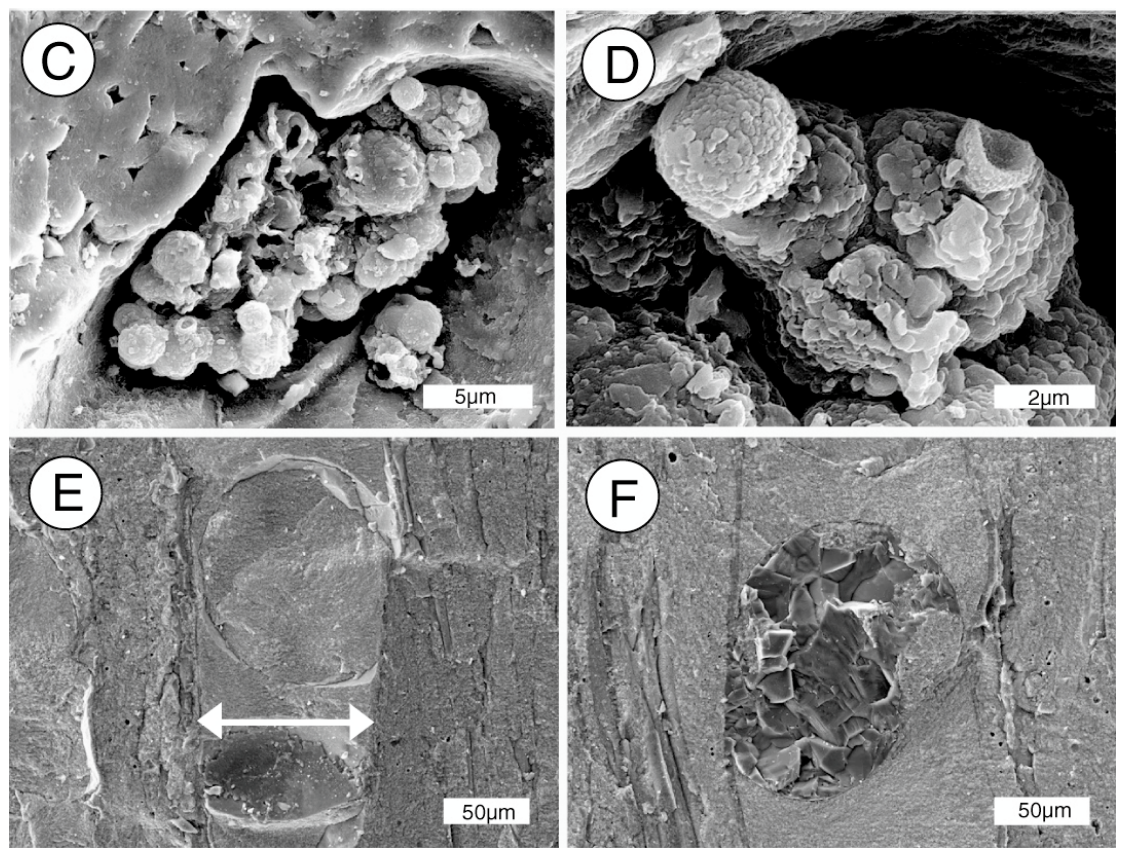

Figure 14. Non-silica minerals. (A,B) Sample CR-40, radial orientation. Tracheids are mineralized with opal-CT, intracellular spaces contain abundant iron pyrite, which partially extends over adjacent tracheids; (C,D) Sample West Shard, oblique radial orientation. Opalized cells surround a vessel that contains framboidal iron pyrite; (E) Sample West Shard, longitudinal view showing vessel mineralized with fine-grained iron oxide; (F) Sample West Shard, transverse view, showing vessel containing calcite crystals. Other nearby vessels contain crystalline quartz.
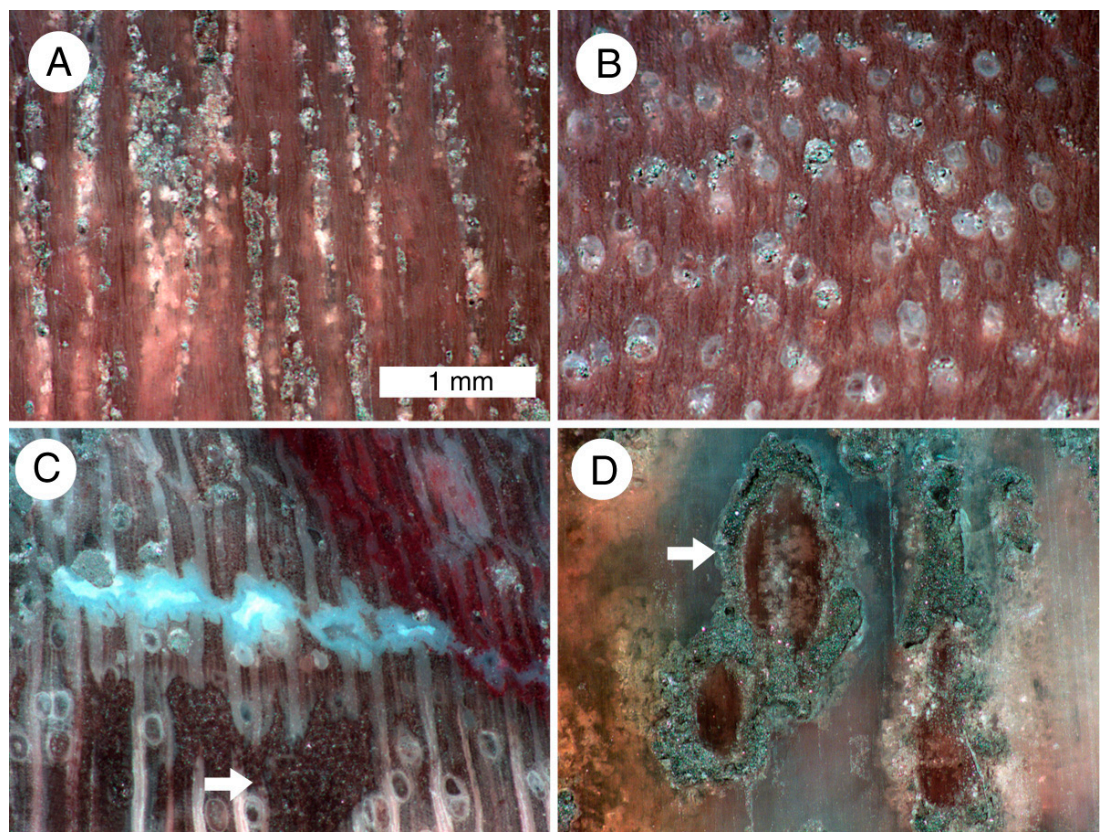

Figure 15. Reflected light photomicrographs of wood specimens that contain pyrite inclusions. (A) Sample CR-1, radial orientation, showing vessel containing pyrite microcrystals; (B) Sample CR-2, transverse orientation. Some vessels contain pyrite, others contain white chalcedony; (C) Sample CR-12, transverse orientation. Irregularly shaped pyrite (arrow) fills a presumed decay area. A horizontal fracture is mineralized with chalcedony, red iron oxide staining at upper right; (D) Sample CR-14, transverse orientation showing chalcedony-filled vessels surrounded by pyrite haloes (arrow). 


\subsection{Trace Elements}

Trace amounts of transition metals are the most common source of color in quartz family minerals [13] and colored gems [14]; these elements also account for the colors observed in most petrified wood. Measured levels of the most common metallic trace elements in 7 Cherokee Ranch specimens are shown in Table 2. These data show low levels for all elements except Fe. The results are consistent with previous research that indicates iron is the dominant element responsible for silicified wood color, with the exception of some bright green specimens that contain high levels of chromium. Bright colored woods from other localities have been reported to contain Fe concentrations $>1000$ ppm [11]; the relatively low Fe levels in the Cherokee Ranch specimens are consistent with the somewhat drab color.

Table 2. Trace metals (ppm) in Cherokee Ranch specimens, determined by LA-ICP-MS.

\begin{tabular}{clcccccccc}
\hline Sample & Ti & $\mathbf{V}$ & $\mathbf{C r}$ & $\mathbf{M n}$ & $\mathbf{F e}$ & $\mathbf{C o}$ & $\mathbf{N i}$ & $\mathbf{C u}$ & $\mathbf{U}$ \\
\hline CR-1 & 12 & 0 & 0 & 7 & 118 & 0 & 2 & 14 & 4 \\
CR-5 & 10 & 9 & 0 & 7 & 124 & 0 & 3 & 19 & 14 \\
CR-12 & 6 & 0.2 & 4 & 4 & 286 & 0.1 & 3 & 16 & 3 \\
CR-14 & 6 & 1 & 14 & 5 & 582 & 0.2 & 3 & 10 & 10 \\
CR-16 & 16 & 1 & 22 & 16 & 336 & 0.3 & 2 & 19 & 37 \\
CR-40 & 5 & 1 & 59 & 4 & 701 & 0.1 & 2 & 32 & 21 \\
W. Shard & 11 & 1 & 33 & 17 & 305 & 0.3 & 2 & 19 & 37 \\
\hline
\end{tabular}

\section{Results \& Discussion}

\subsection{Mineralogy}

The mineralization process that produced Cherokee Ranch fossil wood poses several mysteries. The mineral composition varies among specimens, sometimes even within a single specimen. Specimens may contain only quartz and/or chalcedony, but samples CR- 40 and West Shard have more complex mineralogy. In these samples, cell walls are commonly mineralized with opal, vessel lumina typically contain quartz or chalcedony while tracheid lumina may contain either opal or quartz. The form of opal that mineralizes cell walls in the CR-40 and West Shard samples is uncertain. The isotropic nature of this opal when viewed under polarized light suggests the material is opal-A (Figure 7). In addition, lepispheres resembling opal-A in size and morphology were observed in one SEM specimen (Figure 13C,D). SEM images commonly show smooth-textured opal of uncertain type (Figure 13A,B). However, the Paleocene age of the petrified wood makes the presence of opal-A unlikely because of the rate of transformation [15]; this morphoplogical feature may be evidence of opal-A that has been converted to other silica polymorphs.

As noted earlier, interference colors observed during polarized light optical microscopy are dependent on specimen thickness; opal-CT has low birefringence, and if the relict particle size of opal-A was retained during transformation to opal-CT, the material would perhaps appear to be isotropic. Likewise, the small lepispheres in the West Shard sample may likewise be a relict textural feature. The fine granular texture commonly observed on cell walls in quartz-mineralized specimens (Figure 11D) may be relict opal-A lepispheres. Although XRD patterns would not reveal amorphous opal-A, the patterns confirm that opal-CT is present. Opal-CT is clearly evident in many images (Figures 12D, 13E and 14A,B).

Mineralogic variations have important implications for interpreting the fossilization process. The coexistence of opal and chalcedony in two of the specimens offers important clues for understanding the silicification sequence. A well-accepted paradigm for wood silicification maintains that the process begins with the precipitation of amorphous silica (opal-A) on inner cell walls because of the molecular affinity between silicic acid and hydroxyl groups exposed on wood constituents, especially lignin and holocellulose [16]. Eventually, opal-A may convert to opal-CT, a weakly crystalline 
mixture of cristobalite and tridymite. Ultimately, opal-CT may transform to chalcedony, producing "agatized" petrified wood $[17,18]$. This solid state transformation sequence is well documented for siliceous hot spring sinter [19,20], and for biogenic siliceous sediment [21-24]. In these deposits, the process begins with homogenous opal-A, which successively converts to opal-CT and chert. Applying this silicification model to ancient wood involves the assumption that silica deposition is likewise a homogenous process, resulting in the transformation of opal wood to agatized wood. A chief attraction of this model is that it is corroborated by patterns observed in the geologic record: opalized wood is common in Tertiary formations, but seemingly absent in Mesozoic deposits.

Opal-A is postulated as being the first step in silicification, but this polymorph appears to be rare in fossil wood $[17,18]$. The transformation of opal-A to opal-CT appears to be rapid. Opal-A has been observed in late Miocene wood [25], otherwise opal-A in silicified wood has mostly been reported from wood exposed to modern hot spring environments [26-28]. Transformation rates are related to temperature, but the chemical environment may play a role [29]. Conversion of opal-A to opal-CT in hot springs has been observed to require as little as 50 years, and the subsequent transformation to quartz less than 50,000 years [30,31].

For buried wood, temperatures during diagenesis are primarily a function of burial depth, although local magmatic activity may also affect the geothermal gradient. The presence of lignite seams in the Dawson Arkose suggests that burial temperatures did not exceed $100^{\circ}[32,33]$. Figure 16 shows semiquantitative estimates of temperature-related transformation rates for silica polymorphs. These data confirm the unlikelihood that Paleocene wood might contain opal-A as a primary constituent. The amount of opal-CT relative to quartz would be expected to be very small, which appears to match the mineralogical compositions observed in Cherokee Ranch wood.

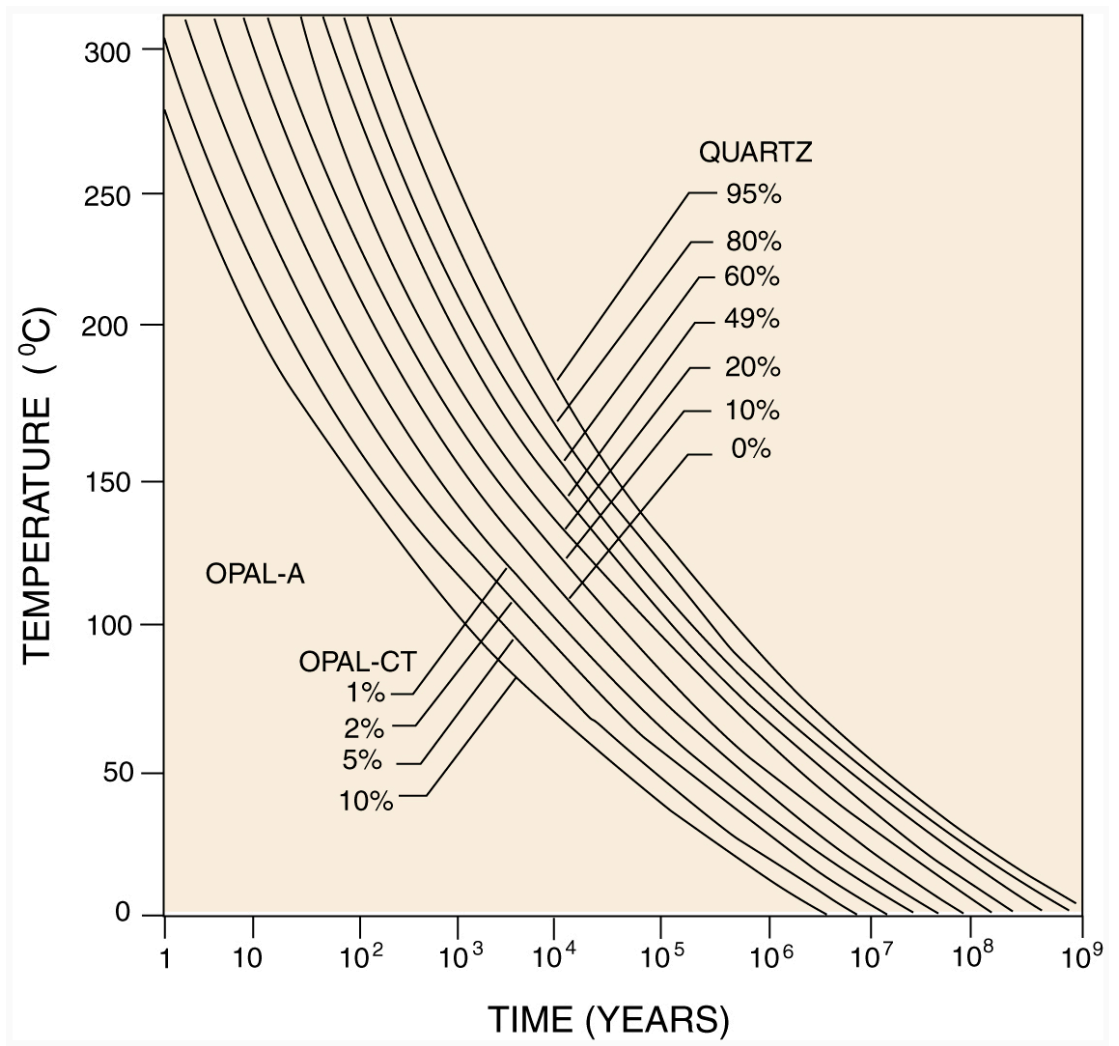

Figure 16. Time/temperature relationships for transformation of opal-A $\rightarrow$ opal-CT $\rightarrow$ quartz. Modified from Mitzutani [18]. 


\subsection{Evidence for Multiple Phases of Mineralization}

The solid-state transformation model described above may be applicable to some, perhaps many, silicified wood occurrences. However, the mineralization of certain silicified woods does not fit this transformation model. Cherokee Ranch appears to be one of those exceptions.

In contrast to the opal-A $\rightarrow$ opal-CT $\rightarrow$ chalcedony transformational sequence, wood mineralization may occur in several discrete mineralization episodes. Buurmann [34]) suggested that wood silicification represented two different processes, opal initially mineralizing cell walls, and cell interiors (lumina) later becoming filled with microcrystalline quartz. Multi-stage silicification processes have been described in detail for Miocene fossil wood from Nevada [25] and Idaho [35], and Eocene wood from Colorado [36].

A solid state transformation process may explain why quartz is the predominant mineral in Cherokee Ranch Petrified Forest. However, the fossil wood contains features that suggest a more complex mineralization process. For buried wood, a possible scenario begins when an early episode of mineralization causes walls to be permineralized with amorphous silica, leaving the majority of tracheid lumina, intracellular spaces, and vessels as open spaces. These spaces later become mineral-filled, where physical/chemical conditions result in precipitation of other silica polymorphs.

Cherokee Ranch samples CR-40 and West Shard show clear evidence of a multi-stage silicification process. The abundance of quartz-filled vessels enclosed by opaline cell walls is a striking feature (Figure 7A). Some areas within these specimens have tracheid and vessel lumina that contain quartz (Figure 7B). In the five specimens that contain only quartz (Figures 11 and 12), the material filling vessels and tracheid lumina has a coarse crystalline texture compared to the adjacent cell wall. These features suggest that cell walls were originally mineralized with opal that has been transformed to chalcedony/quartz. Initially, tracheids and vessels remained open, becoming filled with silica during a later stage of petrifaction. This interpretation is supported by the presence of empty lumina enclosed by opalized cell walls, as observed through SEM (Figure 13A). The presence of subhedral quartz crystals in some vessel lumina further supports the interpretation that silica deposition occurred in successive episodes.

The abundance of volcanic and volcaniclastic rocks in the Denver Basin and the presence of feldspar in the arkosic sandstone matrix accounts for the source of soluble silica; availability of dissolved silica from dissolution of volcanic glass and feldspars during wood petrifaction is well established [37,38].

\subsection{Significance of Non-Silica Minerals}

Cherokee Ranch silicified wood specimens may contain non-silica minerals as minor constituents. Logs in the fossil forest are commonly surrounded by a reddish brown halo of iron oxide, evidence of the presence of dissolved iron in groundwater during diagenesis. Within the fossil wood, ferruginous minerals occur in two forms. Pyrite is the most common iron mineral, observed in the CR- 40 and West Shard specimens. The CR-40 specimen includes zones where pyrite occupies spaces between adjacent tracheids (Figure 14A,B). Pyrite in the CR-40 specimen occurs as framboidal aggregates, where a multitude of small crystals coalesced to form botryoidal masses. In the West Shard specimen, pyrite was observed as well-developed framboids within a single vessel (Figure 14C,D).

The distribution of pyrite in Cherokee Ranch specimens is evident in reflected light photomicrographs (Figure 15), which provide a larger field of view than SEM images. The lower maximum magnification of stereomicroscopy precludes the ability to recognize framboidal textures, and pyrite can be seen to be present in at least three different anatomical environments.

Samples CR-1 and CR-2 both contain local areas where pyrite is abundant as a filling material for vessels (Figure 15A,B). Sample CR-12 contains irregularly-shaped pyrite inclusions that cross-cut wood grain patterns (Figure 15C). These pyrite zones presumably represent ferruginous mineralization of decayed areas. These pyrite distributions are evidence that conditions controlling precipitation of iron sulfides were controlled by local physicochemical variations. Preservation of buried wood is evidence 
of reducing conditions, otherwise the tissue would simply rot. Figure 17 shows the stability fields for various iron minerals. In the presence of disso lved sulfur $\left(\mathrm{SO}_{4}{ }^{2-}\right)$ pyrite will precipitate over a fairly broad range of Eh and $\mathrm{pH}$, and the distribution of pyrite within vessels and void spaces suggests that infusion of iron and sulfur-bearing groundwater did not occur until after most cellular tissue had already been silicified. The occurrence of pyrite haloes surrounding chalcedony-filled vessels in sample CR-14 (Figure 15D) is an enigma. Did the pyrite precipitate around the borders of an empty vessel, which later became silicified? Or is the pyrite a pseuodmorphic replacement for some early mineral? Perhaps the most likely explanation is that organic matter bordering the vessels was replaced by pyrite or marcasite, as evidenced by the rather common occurrence of pyritized plant material in the geologic record. A comparable example is Devonian wood that contains pyritized cell walls with empty cell lumina [39].

Diffuse red-colored zones (e.g., Figure 15C) are consistent with the interpretation that iron oxide minerals are typically present as a result of late-stage diagenetic oxidation, where dissolved iron precipitated as an oxide or hydroxide. The stability field for Fe oxidation is broad, and the formation of ferric oxides likely resulted from low levels of dissolved sulfur (Figure 17). However, as with pyrite genesis, the occurrence of oxidized iron minerals within the fossil wood shows variation. For example, the West Shard specimen contains spheroidal framboids within a vessel, but iron oxide is present in a part of the SEM specimen where a small incipient fracture penetrates the fossil wood. In this zone, vessels are filled with fine-grained iron oxide. The texture shows no pseudomorphic evidence of pyrite; this iron oxide is presumably a primary precipitate. Permeation of iron-bearing solutions appears to have included diffusion into adjacent cell lumina that had previously been mineralized with porous silica, as evidenced by a significant Fe peak in EDS spectra. The ferruginous area shows an additional anomaly, a single vessel that contains crystalline calcite (Figure 14F), in contrast to quartz that fills adjacent vessels.

The occurrence of framboidal pyrite in Cherokee Ranch wood provides clues for understanding geochemical conditions during petrifaction. Framboids are spheroidal or sub-spheroidal aggregates of equidimensional microcrystallites [40]. Various colloidal metal sulfides occur as framboids, but pyrite is by far the most common. Pyrite precipitation requires the availability of Fe and S. In sedimentary environments where organic matter is present, pyrite formation is mainly a chemical process, where dissolved iron is provided by pore water, and sulfur availability is related to hydrogen sulfide generated by sulfate-reducing bacteria. Pyrite precipitation can follow two pathways: euhedral pyrite crystals that typically precipitate directly from solution, and framboids that form from alteration of a colloidal iron sulfate precursor. In sedimentary environments framboids are believed to originate from the reaction of bisulfide and ferrous ions that form aqueous complexes of $\mathrm{Fe}(\mathrm{HS})_{2}$, which are subsequently converted to $\mathrm{FeS}$ (mackinavite) and $\mathrm{Fe}_{3} \mathrm{~S}_{4}$ (greigite). Conversion of these framboids to $\mathrm{FeS}_{2}$ (pyrite) can result from either loss of iron or addition of sulfur [41,42].

The association of pyrite in Cherokee Ranch silicified wood is consistent with a volcaniclastic-rich host sediment that served as a source for both iron and sulfur. Thin layers of conglomerate having oxidized cement occur approximately $30 \mathrm{~m}$ below the D1 petrified wood horizon, and modern groundwater in the region has high iron content. Several factors indicate that framboid formation occurred during a late stage in the petrifaction process. Electron microscopy provides an important clue: Pyrite encrusts the surfaces of opalized tracheids (Figure 14A,B), evidence that iron mineral precipitation occurred after cell walls were permineralized with opal-CT. Pyrite framboids commonly occur in siliceous sediments, suggesting that silica may stabilize the initial iron-rich gel precursor, preserving pyrite fragments that later recrystallize [40]. Development of framboids during a late stage of wood petrifaction is also consistent with the hypothesis that organic matter may inhibit growth or conversion of iron sulfides [41]. 


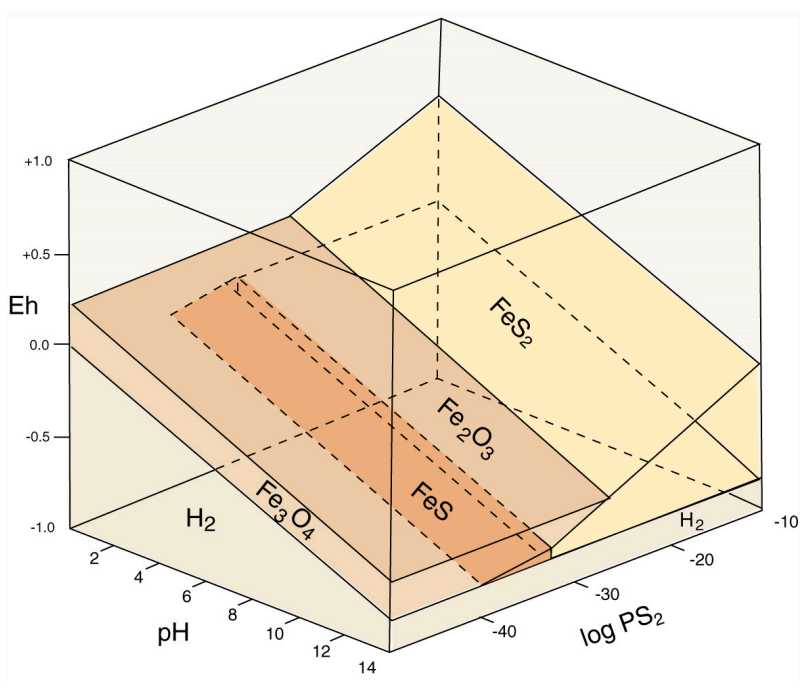

Figure 17. Stability of hematite $\left(\mathrm{Fe}_{2} \mathrm{O}_{3}\right)$, magnetite $\left(\mathrm{Fe}_{3} \mathrm{O}_{4}\right)$, pyrite $\left(\mathrm{FeS}_{2}\right)$ and pyrrhotite $\left(\mathrm{Fe}_{\mathrm{S}}\right)$ as a function of $\mathrm{Eh}, \mathrm{pH}$ and $\log \mathrm{PsS}_{2}$ at $25^{\circ} \mathrm{C}$ and 1 atmosphere total pressure in the presence of water [43].

\subsection{Summary}

The mineralization of Cherokee Ranch fossil wood appears to involve complex processes, involving solid state transformation of silica and multiple episodes of mineral formation. Over time, variation in dissolved Si concentrations may have determined the precipitation of quartz versus opal, with dilute solutions favoring the development of well-ordered lattice structures and high Si concentrations resulting in precipitation of amorphous silica. Two pathways are possible. One interpretation is that the transition from opal to quartz precipitation was a continual process, the switch from opal to quartz being caused by a gradual decline of dissolved silica in groundwater. Alternatively, silicification may have been episodic, involving multiple pulses of groundwater influx, each episode involving solutions having differing $\mathrm{Si}$ concentrations. The episodic model appears to be supported by examples of fossil wood where cellular tissues are mineralized, but lumina and intracellular spaces remain open. This type of preservation implies a single episode of precipitation that silicified cellular tissues, and the absence of a later groundwater influx that might have deposited silica in larger spaces. Episodic groundwater flow could have resulted from a variety of factors: climatic fluctuations that caused precipitation changes, diagentic changes that affected permeability of the matrix, or changes in permeability of the buried wood caused by incipient petrifaction. Changes in temperature, Eh, and $\mathrm{pH}$ may have also played a role during mineralization. Occurrences of non-silica minerals are perhaps explained by variations in concentrations of dissolved $\mathrm{Fe}$ and $\mathrm{S}$ in groundwater, and by local variations in permeability and chemical environment within the wood. Trace element levels are relatively uniform, suggesting that for these elements groundwater concentrations were fairly stable.

As a general synopsis, the sequence of events that produced Cherokee Ranch fossil forest began when logs and woody debris were deposited as driftwood on a sandbar bordering a Paleocene river flowing from the eastern flank of the rising Rocky Mountains. Volcaniclastic- and feldspar-rich sediment provided a source of dissolved silica to groundwater, resulting in partial opalization of the wood tissue, leaving most cell lumina open. These spaces were subsequently filled with chalcedony/quartz at a later time when groundwater $\mathrm{Si} \mathrm{levels} \mathrm{had} \mathrm{decreased.} \mathrm{In} \mathrm{most} \mathrm{logs,} \mathrm{the} \mathrm{original} \mathrm{opal} \mathrm{was} \mathrm{transformed}$ to chalcedony during diagenesis. During late stages of mineralization, pyrite was locally deposited in some specimens, most commonly occurring in intercellular spaces and in vessel lumina. Reddish iron oxides occur infrequently, and appear to relate to the entrance of iron-bearing solutions along fractures late in the petrifaction sequence. 


\subsection{Future Research}

This report is a preliminary investigation that provides a general overview of the fossil forest and a detailed examination of the microscopy and mineralogy of wood specimens. Investigations of the fossil forest have been conducted by members of the Cherokee Ranch Research Institute. A voluntary organization devoted to studying the site. A manuscript is presently being prepared describing the taxonomy of the fossil trees, and a detailed GIS map has been made showing the location of the individual logs and their relation to geology and topography. Hopefully, future reports will describe the geologic setting in greater detail and will discuss human involvement, both anthropological and contemporary, that led to the discovery and preservation of this unique site. Access to the privately owned ranch is carefully controlled, but geologist-led field trips to the fossil forest are occasionally offered to the general public. Schedule information is available at the Cherokee Ranch web site [44].

Acknowledgments: Specimens used in this study, site information, and helpful review comments were provided by the Cherokee Ranch Research Institute members Peter Brown, Al Koch, John McKinney and Tom Michalski. The authors also thank the Cherokee Ranch and Castle Foundation executive director James Holmes. Technical assistance for trace element analyses was provided was Kyle Mikkelson, laboratory manager at the Advanced Materials Science and Engineering Center at Western Washington University. We thank two anonymous reviewers for their constructive suggestions for improving the manuscript.

Author Contributions: Mike Viney assisted in collecting samples for analysis and provided field photos. George E. Mustoe analyzed samples and contributed photomicrographs and graphic art. Both authors participated in writing the manuscript.

Conflicts of Interest: The authors declare no conflicts of interest.

\section{References}

1. Rubino, J. Cherokee Ranch Logs Offer Peak into 55 Million Year of History; The Denver Post: Denver, Colorado, USA, 2015. Available online: http:/ /www.denverpost.com/2015/10/21/cherokee-ranch-logsoffer-peek-into-55-million-years-of-history/ (accessed on 12 December 2016).

2. Raynolds, R.G. Synorogenic and post-orogenic strata in the central Front Range, Colorado. In Geologic History of the Colorado Front Range; Bolyard, D.W., Sonnenberg, S.A., Eds.; American Association of Petroleum Geologists-Rocky Mountain Section Field Trip No. 1997; Rocky Mountain Association of Geologists: Denver, CO, USA, 1997; pp. 43-47.

3. Raynolds, R.G. Upper Cretaceous and Tertiary stratigraphy of the Denver Basin, Colorado. Rocky Mt. Geol. 2002, 37, 111-134. [CrossRef]

4. Raynolds, R.G.; Johnson, K.R. Synopsis of the stratigraphy and paleontology of the uppermost Cretaceous and lower Tertiary strata in the Denver Basin, Colorado. Rocky Mt. Geol. 2003, 38, 171-181. [CrossRef]

5. Tweto, O. Geologic Map of Colorado. In US Geological Survey Special Geologic Map; Scale 1:500,000; USGS: Reston, VA, USA, 1979.

6. Kirkham, R.M.; Ludwig, L.R. Coal Resources of the Denver and Cheyenne Basins, Colorado; Colorado Geological Survey Resources Series 5; Colorado Geological Survey: Golden, CO, USA, 1979; p. 70.

7. Johnson, K.R.; Reynolds, M.L.; Werth, K.W.; Thomasson, J.R. Overview of the Late Cretaceous, early Paleocene, and early Eocene megafloras of the Denver Basin, Colorado. Rocky Mt. Geol. 2003, 38, 101-120. [CrossRef]

8. Barclay, R.S.; Johnson, K.R.; Betterton, W.J.; Dilcher, D.L. Stratigraphy and megaflora of a K-T boundary section in the eastern Denver Basin, Colorado. Rocky Mt. Geol. 2003, 38, 45-71. [CrossRef]

9. Wheeler, E.A.; Michalski, T.C. Paleocene and early Eocene woods of the Denver Basin, Colorado. Rocky Mt. Geol. 2003, 38, 29-43. [CrossRef]

10. Roberts, S.B. Coal in the Front Range Urban Corridor-An Overview of Coal Geology, Coal Production, and Coal-bed Methane Potential in Selected Areas of the Denver Basin, Colorado, and the Potential Effects of Historical Coal Mining on Development and Land-use Planning, Chapter F. In Energy Resource Studies, Northern Front Range, Colorado; Fishman, N.S., Ed.; U.S. Geological Survey Professional Paper 1698; USGS: Reston ,VA USA; pp. 117-162.

11. Mustoe, G.E.; Acosta, M. Origin of petrified wood color. Geosciences 2016, 6, 25. [CrossRef] 
12. Mustoe, G.E. Density and loss on ignition as indicators of the fossilization of silicified wood. IAWA J. 2016, 37, 98-111. [CrossRef]

13. Rossman, G.R. The colored varieties of the silica minerals. In Reviews in Mineralogy; Haney, P.J., Ed.; Mineralogical Society of America: Washington, DC, USA, 1994; pp. 433-468.

14. Fritsch, E.; Rossman, G.R. An update on color in gems, part 1: Introduction and colors caused by dispersed metal ions. Gems Gemol. 1987, 23, 126-139. [CrossRef]

15. Dietrich, D.; Viney, M.; Lampke, T. Petrifactions and wood-templated ceramics: Comparisons between natural and artificial silicification. IAWA J. 2015, 36, 167-185. [CrossRef]

16. Leo, R.F.; Barghoorn, E.S. Silicification of Wood. Harv. Univ. Mus. Leafl. 1976, 25, 1-47.

17. Stein, C.L. Silica recrystallization of petrified wood. J. Sediment. Petrol. 1982, 52, 1277-1282.

18. Scurfield, G.; Segnit, E.R. Petrifaction of wood by silica minerals. Sediment. Geol. 1984, 39, 149-167. [CrossRef]

19. Mizutani, S. Silica minerals in early stages of diagenesis. Sedimentology 1970, 15, 19-36. [CrossRef]

20. Mitzutani, S. Progressive ordering of cristobalitic silica in the early stages of diagenesis. Contrib. Mineral. Petrol. 1977, 61, 419-436.

21. Davis, E.F. The radiolarian cherts of the Franciscan Group. Univ. Calif. Dep. Geol. Bull. 1918, 11, $2235-2432$.

22. Murata, K.J.; Nakata, J.K. Cristobalitic stage in the diagenesis of diatomaceous shale. Science 1974, 184, 567-568. [CrossRef] [PubMed]

23. Ernst, W.G.; Calvert, S.E. An experimental study of the recrystallization of porcellanite and its bearing on the origin of some bedded cherts. Am. J. Sci. 1969, 267A, 114-133.

24. Mustoe, G.E. Diatomaceous origin of siliceous shale in Eocene lake beds of central British Columbia. Can. J. Earth Sci. 2005, 42, 231-241. [CrossRef]

25. Mustoe, G.E. Late Tertiary petrified wood from Nevada, USA: Evidence of multiple silicification pathways. Geosciences 2015, 5, 286-309. [CrossRef]

26. Akahane, H.; Furuno, T.; Miyajima, H.; Yoshikawa, T.; Shiguru, Y. Rapid wood silicification in hot spring water: An explanation of silicification of wood during the Earth's history. Sediment. Geol. 2004, 169, 219-228. [CrossRef]

27. Channing, A.; Edwards, D. Experimental taphonomy: Silicification of plants in Yellowstone hot-spring environments. Trans. R. Soc. Edinb. Earth Sci. 2004, 94, 503-521. [CrossRef]

28. Hellawel, J.; Ballhaus, C.; Gee, C.Y.; Mustoe, G.E.; Nagel, T.; Wirth, R.; Rethemeyer, J.; Tomaschek, F.; Geisler, T.; Greef, K.; et al. Incipient mineralization of recent conifer wood at a Yellowstone hot spring. Geochim. Cosmochim. Acta 2015, 149, 79-87. [CrossRef]

29. Kastner, M.; Keene, J.B.; Gieskes, J.M. Diagenesis of siliceous oozes-1. Chemical controls on the rate of opal-A to opal-CT transformation-An experimental study. Geochim. Cosmochim. Acta 1977, 41, 1041-1059. [CrossRef]

30. Herdianita, N.R.; Browne, P.R.L.; Rodgers, K.A. Mineral and textural changes accompanying aging of silica sinter. Miner. Depos. 2000, 5, 48-62. [CrossRef]

31. Campbell, K.A.; Sannazaro, K.; Rodgers, K.A.; Herdianite, N.; Brown, P.R. Sedimentary facies and mineralogy of late Pleistocene Umukiri sinter, Taupo volcanic zone, New Zealand. J. Sediment. Res. 2001, 71, 727-746. [CrossRef]

32. Bostick, N.H. Microscopic measurement of the level of catagenesis in solid organic matter in sedimentary rocks to aid exploration for petroleum and to estimate burial temperature-A review. In Aspects of Diagenesis; Scolle, P.A., Schluger, P.R., Eds.; Society of Economic Paleontologists and Mineralogists Special Publication: Tulsa, OK, USA, 1979; Volume 26, pp. 17-43.

33. Castaño, J.R.; Sparks, D.M. Interpretation of vitrinite reflectance measurements in sedimentary rocks and determination of burial history using reflectance and authigenic minerals. In Carbonaceous Materials as Indicators of Metamorphism; Dutcher, R.R., Ed.; Geological Society of America Special Paper 153; Geological Society of America: Boulder, CO, USA, 1974; pp. 31-52.

34. Buurman, P. Mineralization of fossil wood. Scr. Geol. 1972, 12, 1-43.

35. Viney, M.; Deitrich, D.; Mustoe, G.; Link, P.; Lampke, T.; Gotze, J.; Rossler, R. Multui-stage silicification of Pliocene wood: Re-examination of an 1985 discovery from Idaho, USA. Geosciences 2016, 6, 21. [CrossRef]

36. Mustoe, G.E. Mineralogy and geochemistry of late Eocene silicified wood from Florissant Fossil Beds National Monument, Colorado. In Paleontology of the Upper Eocene Florissant Formation, Colorado; Meyer, H.W., Smith, D.M., Eds.; Geological Society of America Special Paper 435; Geological Society of America: Boulder, CO, USA, 2008; pp. 127-140. 
37. Murata, K.J. Volcanic ash as a source of silica for silicified wood. Am. J. Sci. 1940, 238, 586-596. [CrossRef]

38. Ballhaus, C.; Gee, C.T.; Bockrath, C.; Greef, K.; Mansfeldt, T.; Rhede, D. Thesilicification of trees in volcanic ash-An experimental study. Geochim. Cosmochim. Acta 2012, 84, 62-74. [CrossRef]

39. Strullu-Dwrriwnm, C.; Kenrick, P.; Tafforeau, P.; Cochard, H.; Bonnemain, J.; Le Hérissé, A.; Lardeux, H.; Badel, E. The earlierst wood and its hydraulic properties documented in c. 407-million-ear-old fossils using synchtroton microtomography. Bot. Soc. Linn. Soc. 2014, 175, 423-437. [CrossRef]

40. Rust, G.W. Colloidal primary copper ores of Cornwall Mines, southwest Missouri. J. Geol. 1935, 43, 398-426. [CrossRef]

41. Sawlowicz, Z. Framboids: From their origin and application. Prace Mineral. (Mineral. Trans.) 2000, 88, 1-58.

42. Sawlowicz, Z. Pyrite framboids and their development: a new conception. Geol. Rundsch. 2000, 82, 148-156. [CrossRef]

43. Garrels, R.M.; Christ, C.L. Solutions, Minerals and Equilibria; Harper and Row, New York and John Weatherhill, Inc.: Tokyo, Japan, 1965.

44. Cherokee Ranch and Castle. Available online: https://cherokeeranch.org/ (accessed on 8 April 2017).

(c) 2017 by the authors. Licensee MDPI, Basel, Switzerland. This article is an open access article distributed under the terms and conditions of the Creative Commons Attribution (CC BY) license (http:/ / creativecommons.org/licenses/by/4.0/). 